\title{
INFLUÊNCIA DOS FENÔMENOS EL NIÑO/LA NIÑA NA PRODUTIVIDADE DE TRIGO NO ESTADO DO PARANÁ
}

\author{
ANGÉlicA PRELA
}

Tese apresentada à Escola Superior de Agricultura “Luiz de Queiroz”, Universidade de São Paulo, para obtenção do título de Doutor em Agronomia, Área de Concentração: Física do Ambiente Agrícola.

P I R A C I C A B A

Estado de São Paulo - Brasil

Dezembro- 2004 


\title{
INFLUÊNCIA DOS FENÔMENOS EL NIÑO/LA NIÑA NA PRODUTIVIDADE DE TRIGO NO ESTADO DO PARANÁ
}

\author{
Angélica Prela
}

Engenheiro Agrônomo

Orientador: Prof. Dr. ANTONIO ROBERTO PEREIRA

\begin{abstract}
Tese apresentada à Escola Superior de Agricultura "Luiz de Queiroz”, Universidade de São Paulo, para obtenção do título de Doutor em Agronomia, Área de Concentração: Física do Ambiente Agrícola.
\end{abstract}

P I R A C I C A B A

Estado de São Paulo - Brasil

Dezembro - 2004 


\section{Dados Internacionais de Catalogação na Publicação (CIP)}

DIVISÃO DE BIBLIOTECA E DOCUMENTAÇÃO - ESALQ/USP

Prela, Angélica

Influência dos fenômenos El Niño/La Niña na produtividade de trigo no Estado do Paraná / Angélica Prela. - - Piracicaba, 2004.

52 p. : il.

Tese (Doutorado) - - Escola Superior de Agricultura Luiz de Queiroz, 2004.

Bibliografia.

1. Balanço hídrico 2. El Niño 3. Grãos - Rendimento 4. Influência climática 5.

Meteo-rologia 6. Produção agrícola 7. Trigo I. Título

CDD 633.11

"Permitida a cópia total ou parcial deste documento, desde que citada a fonte - O autor" 
“ No coração das pessoas existem muitos planos, mas só se realizam aqueles que são da vontade de Deus”.

À minha mãe, por estar sempre ao meu lado,me apoiando em todos os momentos de minha vida;

À minha irmã Solange e às minhas sobrinhas Aline e Heloysa.

DEDICO 


\section{AGRADECIMENTOS}

A Deus,

Ao departamento de Ciências Exatas, da ESALQ/USP, pela acolhida e apoio durante todo o curso.

Ao Prof. Dr. Antonio Roberto Pereira, pela orientação e colaboração nas diversas etapas do curso. Ao Dr. Paulo Henrique Caramori pela co-orientação.

A CAPES, pela concessão de Bolsa de Estudos.

Ao Instituto Agronômico do Paraná, Setor de Agrometeorologia, pela disponibilização das informações necessárias à realização deste trabalho.

Aos Professores Nilson Villa Nova, Sônia Piedade, Quirijn de J. v. Lier, Paulo C. Sentelhas, Luiz R. Angelocci pelo apoio, incentivo, ensinamentos, consideração e amizade.

A Edivaldo, Robson, Fernando, Francisco, Solange e Expedita, funcionários da Esalq/USP.

Aos colegas do programa de pós graduação: Beatriz, Jesus, Cristiane, Luciano, José Eduardo, Santiago, Karazawa, Gustavo, Evandro, Felipe, Ricardo, Fábio, Rafael, Héliton, Alexandre, Adriano, Celso pela amizade e convivência agradável durante o curso.

Ao Marcelo, que passou a fazer parte da minha vida em maio de 2004 e desde então esteve presente em todos os momentos, me dando força, me apoiando, sempre com atenção, carinho e compreensão.

A todos aqueles que direta ou indiretamente colaboraram para a realização deste trabalho. 


\section{SUMÁRIO}

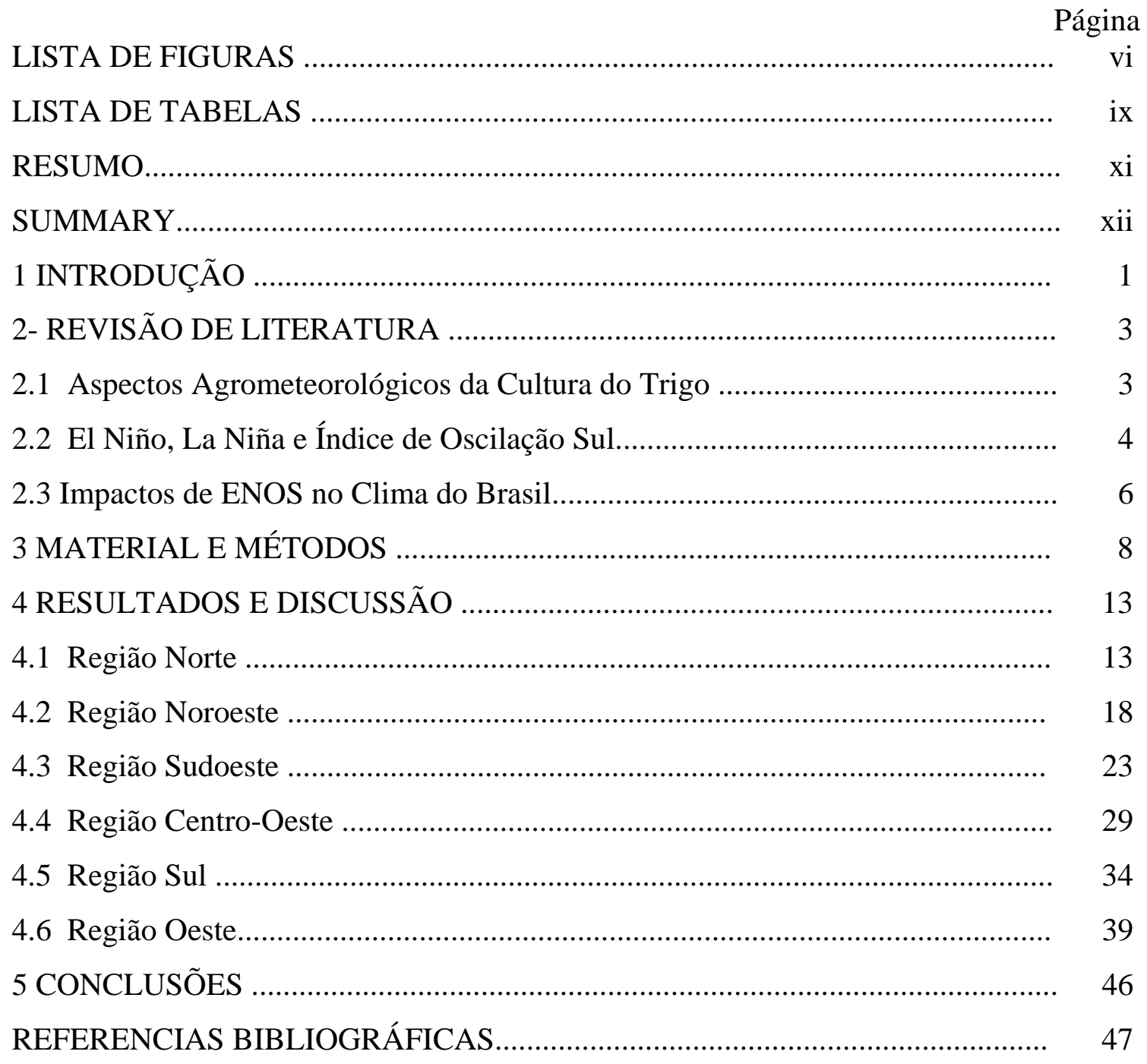




\section{LISTA DE FIGURAS}

Página

1 Estações Meteorológicas do Iapar................................................................ 9

2 Zoneamento da cultura do Trigo no Estado do Paraná (IAPAR, 2002).................. 10

3 Série histórica original (A), corrigida (B) e desvios da média de rendimentos corrigidos (C) de trigo para a região norte do Paraná, de 1976 a 2002.

4 Balanço hídrico climatológico $(\mathrm{CAD}=100 \mathrm{~mm})$ na região norte do Paraná, durante o cultivo em anos de queda da produtividade

5 Balanço hídrico climatológico (CAD = $100 \mathrm{~mm}$ ) na região norte do Paraná, durante o cultivo em anos de acréscimo da produtividade.....

6 Série histórica original (A), corrigida (B) e desvios da média de rendimentos corrigidos (C) de trigo para a região noroeste do Paraná, de 1976 a 2002.

7 Balanço hídrico climatológico $(\mathrm{CAD}=100 \mathrm{~mm})$ na região noroeste do Paraná, durante o cultivo em anos de acréscimo da produtividade. 
8 Balanço hídrico climatológico $(\mathrm{CAD}=100 \mathrm{~mm})$ na região noroeste do Paraná, durante o cultivo em anos de queda da produtividade.

9 Série histórica original (A), corrigida (B) e desvios da média de rendimentos corrigidos (C) de trigo para a região sudoeste do Paraná, de 1976 a 2002.

10 Balanço hídrico climatológico $(\mathrm{CAD}=100 \mathrm{~mm})$ na região sudoeste do Paraná, durante o cultivo em anos de queda da produtividade...

11 Balanço hídrico climatológico $(\mathrm{CAD}=100$ mm) na região sudoeste do Paraná, durante o cultivo em anos de queda da produtividade.

12 Balanço hídrico climatológico $(\mathrm{CAD}=100$ mm) na região sudoeste do Paraná, durante o cultivo em anos de acréscimo da produtividade

13 Série histórica original (A), corrigida (B) e desvios da média de rendimentos corrigidos (C) de trigo para a região centro-oeste do Paraná, de 1976 a 2002

14 Balanço hídrico climatológico $(\mathrm{CAD}=100 \mathrm{~mm})$ na região centro-oeste do Paraná, durante o cultivo em anos de queda da produtividade

15 Balanço hídrico climatológico $(\mathrm{CAD}=100 \mathrm{~mm})$ na região centro-oeste do Paraná, durante o cultivo em anos de acréscimo da produtividade.

16 Série histórica original (A), corrigida (B) e desvios da média de rendimentos corrigidos (C) de trigo para a região sul do Paraná, de 1976 a 2002 
17 Balanço hídrico climatológico $(\mathrm{CAD}=100 \mathrm{~mm})$ na região sul do Paraná, durante o cultivo em anos de acréscimo da produtividade

18 Balanço hídrico climatológico $(\mathrm{CAD}=100 \mathrm{~mm})$ na região sul do Paraná, durante o cultivo em anos de queda da produtividade.

19 Série histórica original (A), corrigida (B) e desvios da média de rendimentos corrigidos (C) de trigo para a região oeste do Paraná, de 1976 a

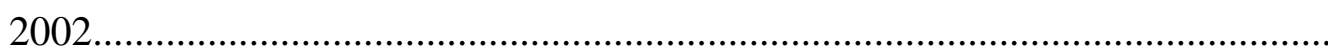

20 Balanço hídrico climatológico (CAD = $100 \mathrm{~mm}$ ) na região oeste do Paraná, durante o cultivo em anos de acréscimo da produtividade..................................

21 Balanço hídrico climatológico $(\mathrm{CAD}=100 \mathrm{~mm})$ na região oeste do Paraná, durante o cultivo em anos de queda da produtividade....................................... 


\section{LISTA DE TABELAS}

Página

1 Índices de Oscilação Sul mensal, 1976 a 2002.................................................. 11

2 Regiões de cultivo, estações meteorológicas, localização geográfica épocas de semeadura de trigo no Paraná......................................................................... 12

3 Sinal de valores mensais de Índice de Oscilação Sul (IOS) e desvio da produtividade de trigo na região norte do Paraná, de 1976 a 2002 _..................... 18

4 Sinal de valores mensais de Índice de Oscilação Sul (IOS) e desvio da produtividade de trigo na região noroeste do Paraná, de 1976 a 2002..................

5 Sinal de valores mensais de Índice de Oscilação Sul (IOS) e desvio da produtividade de trigo na região sudoeste do Paraná, de 1976 a 2002...................

6 Sinal de valores mensais de Índice de Oscilação Sul (IOS) e desvio da produtividade de trigo na região centro-oeste do Paraná, de 1976 a

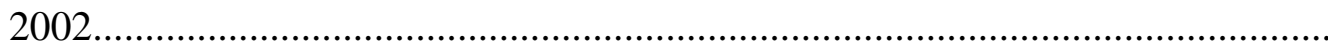

7 Sinal de valores mensais de Índice de Oscilação Sul (IOS) e desvio da produtividade de trigo na região sul do Paraná, de 1976 a 2002........................... 
8 Sinal de valores mensais de Índice de Oscilação Sul (IOS) e desvio da produtividade de trigo na região oeste do Paraná, de 1976 a

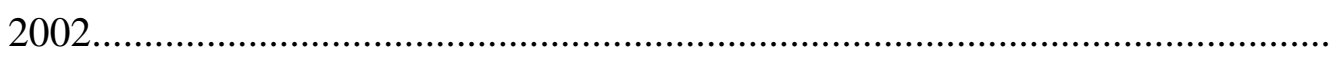




\section{INFLUÊNCIA DOS FENÔMENOS EL NIÑO/LA NIÑA NA PRODUTIVIDADE DE TRIGO NO ESTADO DO PARANÁ}

AUTOR: ANGÉLICA PRELA

ORIENTADOR: PROF. DR. ANTONIO ROBERTO PEREIRA

\section{RESUMO}

O objetivo deste estudo foi verificar as influências dos fenômenos El Niño/La Niña (EN/LN) no rendimento regional de trigo cultivado no Paraná entre 1976 e 2002. Os dados de produtividade foram obtidos junto à SEAB e os meteorológicos junto ao IAPAR, e agrupados em 6 regiões produtoras (norte, noroeste, oeste, sudoeste, sul e centro-oeste). A tendência tecnológica da série de cada região foi eliminada para facilitar a associação entre a ocorrência dos eventos EN/LN e os desvios na produtividade regional. O balanço hídrico climatológico seqüencial de ThornthwaiteMather $(\mathrm{CAD}=100 \mathrm{~mm})$ na escala decendial permitiu detectar a situação da umidade do solo regional durante o período de cultivo em cada ano com desvio significativo de produtividade. Verificou-se queda do rendimento em anos de El Niño nas regiões centro-oeste e oeste, e tendência a acréscimo ao rendimento em anos de La Niña na região sul. Para as regiões norte, noroeste e sudoeste não foi encontrado efeito significativo desses fenômenos sobre o rendimento regional. 


\title{
INFLUENCE OF EI NIÑO/LA NIÑA IN PRODUCTIVITY OF WHEAT IN PARANÁ STATE
}

\author{
AUTHOR: ANGÉLICA PRELA \\ ADVISER: PROF. DR. ANTONIO ROBERTO PEREIRA
}

SUMMARY

The aim of this study was to verify the influences of El Niño/La Niña (EN/LN) in the regional yield of wheat in Paraná from 1976 to 2002. The yield and meteorological data were grouped in 6 regions, i.e., north, northwest, west, south, southwest, and central west. The technological trend of the yield series was eliminated to allow associations between the occurrence of the events EN/LN and the deviation of regional yield. Sequential climatological Thornthwaite-Mather water balance (SWC = $100 \mathrm{~mm}$ ) on a 10-days time scale was used to detect the regional soil moisture conditions during the growth period in each year with large yield deviation. There was yield decrease in years of EN in the center-west and west regions, and tendency of yield increase in LN years in the south region. In the north, northwest, and southwest regions there was no significant effect of the EN/LN on the regional wheat yield. 


\section{INTRODUÇÃO}

O Estado do Paraná é um dos grandes produtores agrícolas do Brasil. A produção agrícola gera diretamente cerca de 33\% da arrecadação de impostos do estado, sendo que outros 30\% são devidos à transformação de produtos agrícolas (Bragagnolo, 1992). A produção atual de trigo no estado do Paraná representa cerca de $50 \%$ da produção brasileira (IBGE, 2004).

Os trigos cultivados no Paraná pertencem ao grupo denominado primavera (Manfron et al., 1993). Essas cultivares têm ciclo total de 100 a 130 dias, não necessitam de frio intenso para desenvolvimento da espiga e são indiferentes ao fotoperíodo (Doorenbos \& Kassam, 1979). Porém, a produtividade depende das condições hídricas durante o período de formação dos órgãos reprodutivos e na floração (Lomas, 1976). Falta de água nessas épocas reduz o número de grãos por espiga e o rendimento da cultura. Chuvas freqüentes durante o inverno, além de intensificar as moléstias, prejudicam a qualidade e produtividade quando coincide com a colheita sendo comum a germinação do grão ainda na espiga e o acamamento da planta (Dario, 1988; Linhares \& Nedel, 1989; Fontana \& Berlato, 1997; Cunha et al., 1999).

É fato conhecido que a variabilidade interanual das chuvas é determinante da variabilidade dos rendimentos e da produção agrícola (Berlato, 1992a, b; Berlato et al., 1992). No norte do Paraná, as precipitações são mais escassas no inverno, e o trigo pode sofrer com secas (Silva et al., 1973); enquanto que, no sul do estado a cultura pode ser prejudicada por geadas e granizo. O sucesso do cultivo de trigo depende da seqüência de um período inicial com plena umidade no solo, para garantir germinação e crescimento vegetativo, seguido por 6 a 8 semanas com pouca chuva e muita insolação para permitir 
pleno enchimento dos grãos e sua maturação, sempre com temperaturas médias entre 18 e $19{ }^{\circ} \mathrm{C}$ (Kirkham \& Kanemasu, 1983).

Nem todo evento El Niño/La Nina (EN/LN) causa impacto negativo sobre o rendimento de grãos no Brasil (Cunha et al. 1999). O impacto depende da intensidade do fenômeno e da anomalia causada no regime de chuvas. Durante eventos EN observa-se aumento de chuvas na região sul do Brasil, principalmente na primavera, no fim do outono e no começo de inverno. No Paraná, os efeitos do EN dependem da cultura, e do calendário agrícola, pois a falta de chuvas em determinadas fases do cultivo independe da ocorrência do fenômeno (Guerra \& Caramori, 2002). Anos sem ocorrência de EN/LN apresentaram anomalias significativas de precipitação no Paraná, indicando que elas nem sempre estão associadas diretamente à ocorrência de EN/LN (Nery et al., 1997, 2002).

Este estudo tem por objetivo verificar a influência dos eventos EN/LN na produtividade regional de trigo no Paraná entre 1976 e 2002. Trata-se de uma avaliação qualitativa dos efeitos desses fenômenos sobre o rendimento agrícola regional. 


\section{REVISÃO DE LITERATURA}

\subsection{Aspectos Agrometeorológicos da Cultura do Trigo}

O cultivo comercial do trigo farináceo (Triticum aestivum L.) se encontra entre as latitudes $20^{\circ}$ e $55^{\circ} \mathrm{N}$, e entre $20^{\circ}$ e $40^{\circ} \mathrm{S}$, em regiões com invernos amenos e sem chuvas fortes (Mota, 1982, 1989; Kirkham \& Kanemasu, 1983; Dario, 1988; Manfron et al., 1993).

A temperatura ideal para o crescimento do trigo está entre $15{ }^{0} \mathrm{C}$ e $20{ }^{0} \mathrm{C}$ para o perfilhamento, e entre $20{ }^{0} \mathrm{C}$ e $25{ }^{0} \mathrm{C}$ para germinação e desenvolvimento foliar (Evans et al., 1975; Doorenbos \& Kassam, 1979; Mota, 1989; Manfron et al., 1993). A temperatura mínima para que haja crescimento (temperatura base) está entre $2{ }^{0} \mathrm{C}$ na fase inicial de desenvolvimento, e $9{ }^{0} \mathrm{C}$ durante o período de enchimento dos grãos (Manfron et al., 1993). Temperaturas extremas causam mais danos durante os períodos de espigamento, floração e enchimento dos grãos resultando em esterilização e perda de produção. Nesses períodos o trigo é sensível a geadas, e temperatura mínima de $-2{ }^{0} \mathrm{C}$ na floração provoca esterilidade, e de $-4{ }^{0} \mathrm{C}$ na formação dos grãos, provoca chochamento dos grãos (Mota, 1989; Manfron et al. 1993). Temperatura máxima acima de $26{ }^{0} \mathrm{C}$ reduz o período de enchimento dos grãos com perda de produção (Laing \& Fischer, 1975; Mota, 1989; Manfron et al. 1993). Temperatura elevada aumenta a transpiração e a respiração, e diminui a umidade relativa do ar secando mais rapidamente as flores, diminuindo o período fértil.

A ocorrência de chuvas leves é ideal no início do cultivo facilitando a germinação, o perfilhamento, o emborrachamento e a floração (Lomas, 1976; Mota, 1989). Pequenos períodos com deficiência hídrica fora dessas fases críticas não afetam 
significativamente o rendimento da cultura (Lomas, 1976; Manfron et al., 1993). Na maturação, chuvas freqüentes com temperatura entre 20 e $25{ }^{0} \mathrm{C}$ e alta umidade relativa do ar aumentam a incidência de moléstias, podendo os grãos germinar ainda na espiga alterando sua qualidade (Silva, 1971; Godoy \& Bernardes, 1989; Linhares \& Nedel, 1989; Manfron et al., 1993). Espigas encharcadas podem causar acamamento da planta dificultando a colheita (Silva, 1971; Dario, 1988).

As necessidades hídricas durante o ciclo de cultivo variam de 450 a 650 mm (Doorenbos \& Kassam, 1979). No período espigamento-enchimento de grãos a relação entre evapotranspiração real e de referência (potencial, ETP) não deve ser inferior a 0,85 (Mota, 1982). Isso significa que a chuva ideal deve ser próxima de 85\% da ETP para não causar prejuízos nem por falta nem por excesso de umidade.

\subsection{El Niño, La Niña e Índice de Oscilação Sul}

O fenômeno El Niño (EN) é conhecido como o maior causador de condições meteorológicas anômalas (secas e chuvas extremas) afetando a circulação atmosférica em escala global (Katz, 2002). Esse fenômeno ocorre no Oceano Pacífico entre a América do Sul e a Austrália em função da diferença de temperatura da superfície do oceano nessas regiões. A condição mais comum é a temperatura do mar ser de $3^{\circ} \mathrm{C}$ a $8^{\circ} \mathrm{C}$ maior na região australiana. Tal diferença térmica impõe um gradiente de pressão atmosférica resultando em ventos de leste que arrastam as águas quentes superficiais em direção à Austrália. Os movimentos convectivos se intensificam sobre as águas mais aquecidas com conseqüente aumento nas chuvas locais. As águas mais frias afloram na costa oeste da América do Sul e inibem os movimentos convectivos na região resultando em períodos longos sem chuvas significativas.

Em alguns anos, por motivos ainda não comprovados cientificamente e sem

periodicidade bem definida, o padrão de diferença térmica se rompe diminuindo o gradiente de pressão atmosférica, enfraquecendo progressivamente os ventos do leste. Nessas condições, as chuvas diminuem na costa australiana e se intensificam no oeste da 
América do sul. Águas quentes são menos abundantes em peixes e os pescadores observam queda acentuada em suas rendas. Na costa do Peru e Equador essa condição geralmente se intensifica em dezembro, próximo ao natal, e os pescadores associam tal fenômeno com o nascimento do menino Jesus, denominando-o El Nino (EN).

Estudando as possíveis causas das variações das monções na Índia, Sir Gilbert Walker (1868-1958) notou associação entre a variação da pressão atmosférica em Taiti (Pacifico Central) e aquela que ocorre em Darwin (norte da Austrália). Quando a pressão aumenta em Taiti há decréscimo na pressão em Darwin, e vice-versa. A essa aparente gangorra barométrica leste-oeste Walker, em 1928, denominou de Oscilação Sul (OS). Walker observou que, quando a pressão é muito alta em Taiti e baixa em Darwin, as chuvas são intensas na Austrália, sudeste Asiático e Índia, e quase inexistentes na costa oeste da América do Sul. A situação das chuvas inverte quando a pressão diminui em Taiti e aumenta em Darwin. Esse fenômeno inverso do EN é denominado La Nina (LN).

Com o início de lançamento de satélites artificiais na década de 1960 foi possível obter-se imagens globais da temperatura da superfície terrestre. Com base nessas observações Jacob Bjerknes (1897-1975) associou a ocorrência do EN com a Oscilação Sul, gerando o termo ENOS para acoplar o fenômeno oceânico com o meteorológico.

A OS é representada por um índice (IOS) que expressa sua fase e sua intensidade. IOS é determinado pela diferença entre os desvios de pressão atmosférica ao nível do mar (PNM) registradas no Taiti, no pacifico Central, e Darwin, ao norte da Austrália. A fase positiva do IOS (LN) ocorre quando o sistema de altas pressões do Pacífico Oriental e o de baixas pressões na Indonésia se intensificam. Quando a PNM em Taiti se eleva acima de sua média ao mesmo tempo em que Darwin se reduz abaixo da sua média tem-se um IOS positivo. Nessas condições, aumentam as precipitações sobre a Indonésia e o norte da Austrália.

Na fase negativa do IOS (EN) o sistema de baixa pressão, na Indonésia e no norte da Austrália, e de alta pressão, no Pacífico Oriental, enfraquece. O gradiente horizontal de PNM se reduz e os ventos alísios diminuem de intensidade, chegando, por 
vezes, a tomar o sentido inverso na parte ocidental do Pacífico. Com isso, o transporte de águas oceânicas e a ressurgência diminuem dando lugar às ondas de Kelvin (Molion, 1989), que é o retorno das águas quentes superficiais para a costa oeste da América do Sul. Há deslocamento do ramo ascendente da célula de circulação do tipo Walker para a parte central do Oceano Pacífico, fazendo com que ilhas nessa região experimentem excessos de chuvas, onde são normalmente escassas (Cunha, 1995). A tendência do EN ocorrer no verão do hemisfério sul indica que o ciclo sazonal tem papel importante na OS (Kousky \& Cavalcanti, 1984).

O ENOS ocorrido entre outubro de 1997 e janeiro de 1998 foi considerado como a mais forte manifestação do fenômeno no século XX e as águas da costa do Peru ficaram cerca de $4^{\circ} \mathrm{C}$ acima do normal.

\subsection{Impactos de ENOS no Clima do Brasil}

A região sul brasileira apresenta forte sinal do ENOS na variabilidade das chuvas (Rao \& Hada, 1990; Studzinski, 1995; Fontana \& Berlato, 1997; Grimm et al., 1997). A correlação entre OS e precipitação no Rio Grande do Sul é expressiva tanto para o trimestre da estação chuvosa quanto para o trimestre que a antecede (Rao \& Hada, 1990). Em anos de EN aumenta as chuvas, principalmente na primavera, no fim do outono e no começo de inverno. Acréscimo de até $150 \%$ em relação ao seu valor normal em alguns locais faz com que a chuva atrapalhe a colheita e prejudique o rendimento da safra, principalmente de grãos (Fontana \& Berlato, 1997; Cunha et al., 1999).

Durante a transição do inverno para a primavera, o EN pode causar aumento de temperatura e redução da umidade, o que torna a área mais suscetível a queimadas e incêndios. Os invernos tendem a ser mais amenos na região sul, e no sudeste as temperaturas ficam ainda mais altas em relação ao seu valor normal.

No Nordeste, o índice pluviométrico fica abaixo do normal, causando estiagem mais severa, no princípio do verão. Isso porque o aumento da temperatura das 
águas do oceano Pacífico afeta a instabilidade das massas de ar frio, que, no caso do Brasil, ficam estacionadas na região Sul. Algumas áreas do sertão nordestino podem ficar sem registrar nenhuma chuva. Assim, as secas podem durar até 2 anos em períodos de EN (Rao et al.; 1993; Alves et al., 1997). Períodos de seca não se limitam apenas ao sertão e até mesmo no litoral pode haver falta de chuvas (www.climabrasileiro.hpg.ig.com.br/ nino.htm, acesso em 19/03/2004).

Condições relativamente secas prevalecem sobre a região nordeste do Brasil e sobre parte da Bacia Amazônica durante o verão Austral da fase negativa da OS (Aceituno, 1988). Sinais mais fracos, com tendência de condições mais úmidas, foram observados por esse autor na Bacia do Rio Paraná, no período inicial do verão. 


\section{MATERIAL E MÉTODOS}

Uma série histórica (1976 a 2002) da produtividade média regional do trigo foi obtida junto à Secretaria Estadual da Agricultura e Abastecimento do Estado do Paraná (SEAB). O rendimento médio de 6 regiões mostrou tendência de aumento ao longo do período analisado, e isto foi devido à melhoria das condições de cultivo e denominado de tendência tecnológica (TT). Essa TT dificulta a deteç̧ão de possíveis efeitos (positivos ou negativos) dos eventos El Nino/La Nina (EN/LN) sobre o rendimento médio regional. A TT de cada região foi determinada por uma análise de regressão linear simples considerando o ano como variável independente $\left(X_{i}\right)$ na série original de produtividade $\left(Y_{i}\right)$. A TT foi removida da série original resultando numa série corrigida, ou seja, $Y_{c i}=Y_{i}-\left(Y_{X i}-Y_{0}\right)$ em que $Y_{i}$ é o rendimento original do ano $i, Y_{X i}$ é o rendimento do ano $i$ estimado pela regressão e $Y_{0}$ é o rendimento do primeiro ano da série histórica estimado pela regressão (CUNHA et al., 2001). Assim, as variações de produtividade podem ser atribuídas aos efeitos climáticos.

Os impactos dos eventos EN/LN sobre o rendimento médio da cultura de trigo no Estado foram avaliados separadamente nas seis regiões produtoras. De 1976 a 2002 ocorreram 10 eventos EN (1976, 1977, 1982, 1986, 1991, 1992, 1993, 1994, 1997 e 1998) e 6 LN (1988, 1995, 1996, 1999, 2000 e 2001). A ocorrência de EN/LN foi obtida junto ao Instituto Nacional de Pesquisas Espaciais (INPE, 2004) e também em NERY et al. (2002).

A disponibilidade hídrica regional foi avaliada com balanço hídrico climatológico seqüencial de Thornthwaite-Mather (CAD=100 mm) durante a 
estação de cultivo, em escala decendial, apenas em anos que a produtividade apresentou grandes desvios.

Dados de 20 estações meteorológicas das regiões de cultivo foram obtidos no Instituto Agronômico do Paraná (IAPAR) e utilizados para obter a média regional do período de cultivo (Figura 1). O número de estações variou de duas, nas regiões centrooeste e Sudoeste, a cinco, nas regiões norte e oeste. A localização geográfica e a época de semeadura em cada região de cultivo estão descritas na Tabela 2. A regionalização utilizada foi definida pelo zoneamento agroclimático da cultura do trigo apresentada na Figura 2 (Godoy \& Bernardes, 1989; IAPAR, 2002), e difere daquela apresentada por NERY et al. (1996; 2002) para as chuvas.

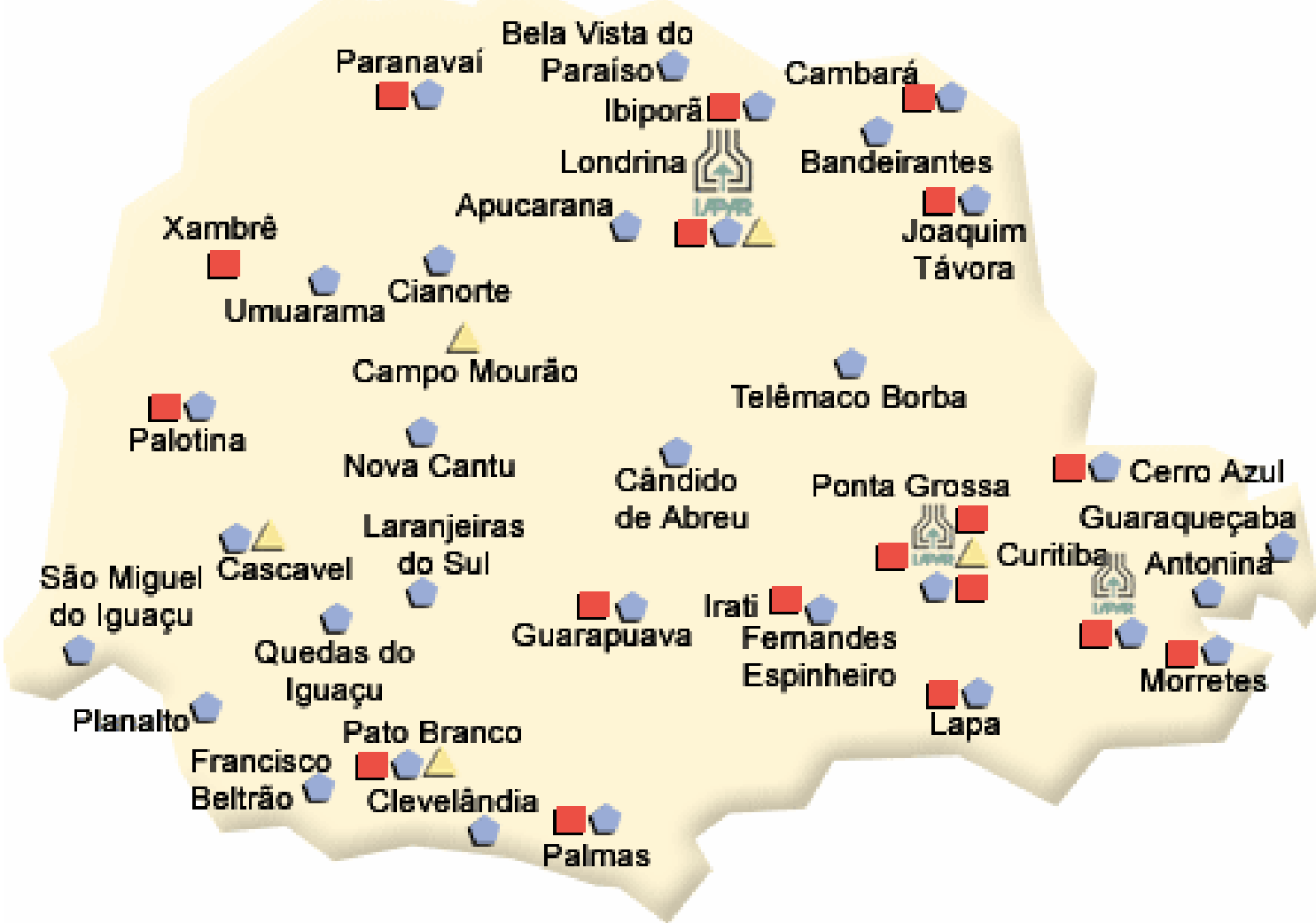

Figura 1 - Estações meteorológicas do IAPAR 


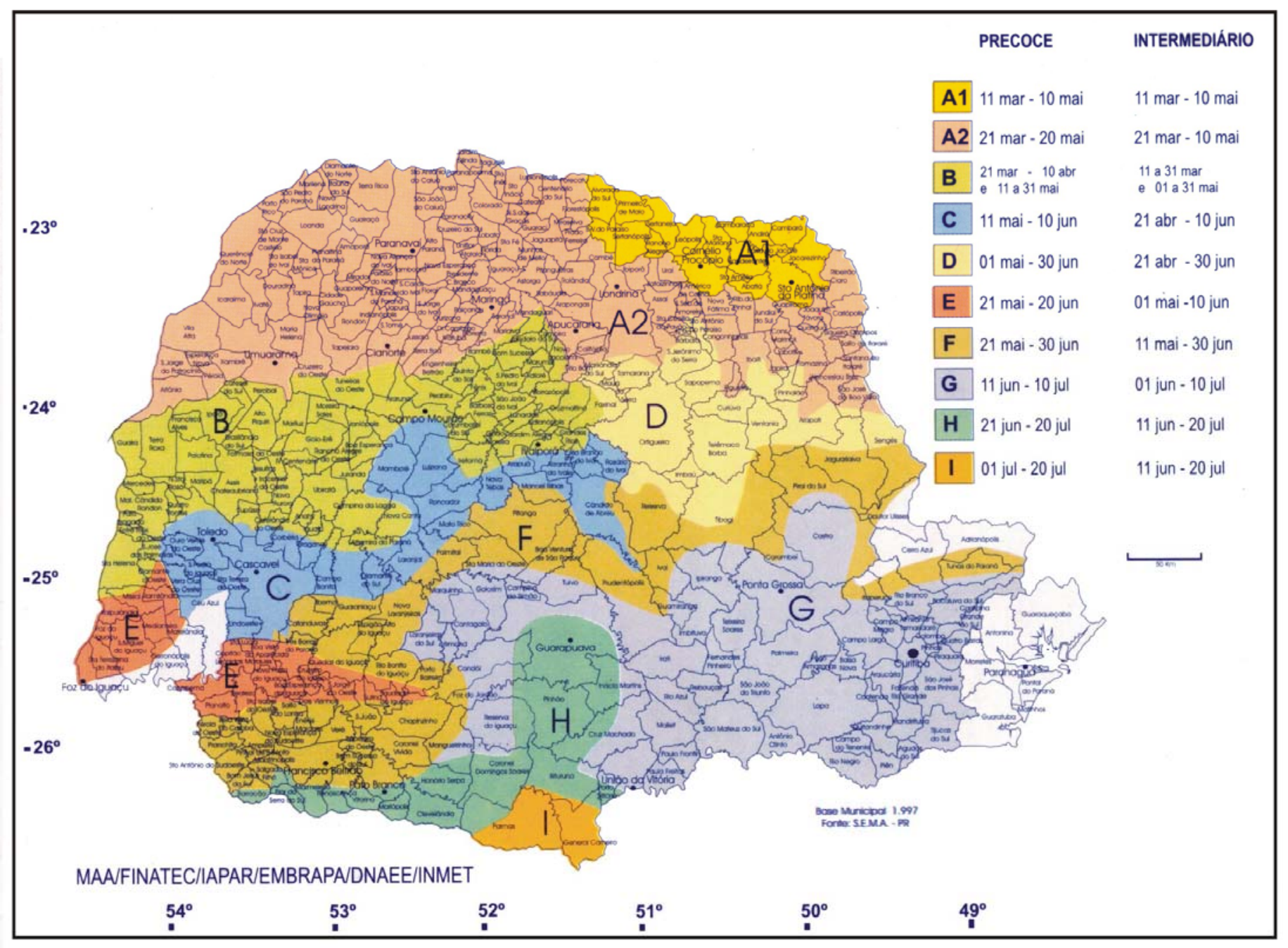

Figura 2- Zoneamento da cultura do Trigo no Estado do Paraná (IAPAR, 2002) 
Tabela 1.Índices de Oscilação Sul mensal, 1976 a 2002

\begin{tabular}{|c|c|c|c|c|c|c|c|c|c|c|c|c|}
\hline Ano & Jan & $\mathbf{F e v}$ & Mar & Abr & Mai & Jun & Jul & Ago & Set & Out & Nov & Dez \\
\hline 1976 & 1,5 & 1,6 & 1,3 & 0,1 & 0,2 & $-0,1$ & $-1,2$ & $-1,3$ & $-1,4$ & 0,2 & 0,7 & $-0,6$ \\
\hline 1977 & $-0,7$ & 1,1 & $-1,3$ & $-0,8$ & $-0,9$ & $-1,5$ & $-1,5$ & $-1,3$ & $-1,0$ & $-1,4$ & $-1,6$ & -1.4 \\
\hline 1978 & $-0,4$ & -3.5 & $-0,8$ & $-0,6$ & 1,3 & 0,3 & 0,4 & 0,0 & 0,0 & $-0,7$ & $-0,1$ & $-0,3$ \\
\hline 1979 & $-0,7$ & 0,8 & $-0,5$ & $-0,4$ & 0,3 & 0,4 & 1,3 & $-0,6$ & 0,1 & $-0,4$ & $-0,6$ & $-1,0$ \\
\hline 1980 & 0,3 & 0,0 & $-1,2$ & $-1,0$ & $-0,3$ & $-0,4$ & $-0,2$ & 0,0 & $-0,6$ & $-0,3$ & $-0,5$ & $-0,3$ \\
\hline 1981 & 0,2 & $-0,6$ & $-2,1$ & $-0,4$ & 0,7 & 1,0 & 0,8 & 0,4 & 0,4 & $-0,7$ & 0,1 & 0,5 \\
\hline 1982 & 1,3 & $-0,1$ & 0,1 & $-0,2$ & $-0,7$ & $-1,6$ & $-1,9$ & $-2,5$ & $-2,0$ & $-2,2$ & $-3,2$ & $-2,8$ \\
\hline 1983 & $-4,2$ & $-4,6$ & $-3,4$ & $-1,3$ & 0,5 & $-0,3$ & $-0,8$ & $-0,2$ & 1,0 & 0,3 & $-0,2$ & $-0,1$ \\
\hline 1984 & 0,1 & 0,6 & $-0,9$ & 0,2 & 0,0 & $-0,8$ & 0,0 & 0,0 & 0,1 & $-0,6$ & 0,2 & $-0,4$ \\
\hline 1985 & $-0,5$ & 1,0 & 0,2 & 1,0 & 0,2 & $-0,9$ & $-0,3$ & 0,7 & 0,0 & $-0,7$ & $-0,3$ & 0,1 \\
\hline 1986 & 0,0 & $-1,6$ & 0,0 & 0,1 & $-0,5$ & 0,7 & 0,1 & $-1,0$ & $-0,6$ & 0,5 & $-1,5$ & $-1,8$ \\
\hline 1987 & $-0,9$ & $-1,9$ & $-2,0$ & $-1,9$ & $-1,7$ & $-1,7$ & $-1,7$ & $-1,5$ & $-1,2$ & $-0,7$ & -0.1 & $-0,7$ \\
\hline 1988 & $-0,2$ & $-0,9$ & 0,1 & $-0,1$ & 0,8 & $-0,2$ & 1,1 & 1,4 & 2,1 & 1,4 & 1,9 & 1,3 \\
\hline 1989 & 1,7 & 1,1 & 0.6 & 1,6 & 1,2 & 0,5 & 0,8 & $-0,8$ & 0,6 & 0,6 & $-0,4$ & $-0,7$ \\
\hline 1990 & $-0,2$ & $-2,4$ & $-1,2$ & 0,0 & 1,1 & 0,0 & 0,5 & $-0,6$ & $-0,8$ & 0,1 & $-0,7$ & $-0,5$ \\
\hline 1991 & 0,6 & $-0,1$ & $-1,4$ & $-1,0$ & $-1,5$ & $-0,5$ & $-0,2$ & $-0,9$ & $-1,8$ & $-1,5$ & $-0,8$ & $-2,3$ \\
\hline 1992 & $-3,2$ & $-1,4$ & $-3,0$ & $-1,4$ & 0,0 & $-1,2$ & $-0,8$ & 0,0 & 0,0 & $-1,9$ & $-0,9$ & $-0,9$ \\
\hline 1993 & $-1,2$ & $-1,3$ & $-1,1$ & $-1,6$ & $-0,6$ & $-1,4$ & $-1,1$ & $-1,5$ & $-0,8$ & $-1,5$ & $-0,2$ & 0,0 \\
\hline 1994 & $-0,3$ & $-0,1$ & $-1,4$ & $-1,8$ & $-1,0$ & $-0,9$ & $-1,8$ & $-1,8$ & $-1,8$ & $-1,6$ & $-0,7$ & $-1,6$ \\
\hline 1995 & $-0,6$ & $-0,5$ & 0,2 & $-1,1$ & $-0,7$ & $-0,2$ & 0,3 & $-0,1$ & 0,3 & $-0,3$ & 0,0 & $-0,8$ \\
\hline 1996 & 1,0 & $-0,1$ & 0,7 & 0,6 & 0,1 & 1,0 & 0,6 & 0,4 & 0,6 & 0,4 & $-0,2$ & 0,8 \\
\hline 1997 & 0,5 & 1,6 & $-1,1$ & $-0,9$ & $-1,8$ & $-2,0$ & $-1,0$ & $-2,1$ & $-1,6$ & $-1,9$ & $-1,4$ & $-1,3$ \\
\hline 1998 & $-3,3$ & $-2,7$ & $-3,5$ & $-1,9$ & 0,1 & 0,7 & 1,3 & 1,0 & 1,2 & 1,0 & 1,1 & 1,4 \\
\hline 1999 & 2,0 & 0,8 & 0,9 & 1,4 & 0,1 & $-0,1$ & 0,5 & 0,1 & $-0,1$ & 0,9 & 1,1 & 1,5 \\
\hline 2000 & 0,7 & 1,6 & 1,0 & 1,2 & 0,2 & $-0,6$ & $-0,4$ & 0,4 & 1,0 & 1,0 & 2,0 & 0,7 \\
\hline 2001 & 1,1 & 1,5 & 0,5 & $-0,1$ & $-0,8$ & $-0,1$ & $-0,4$ & $-1,0$ & 0,2 & $-0,4$ & 0,7 & $-1,2$ \\
\hline 2002 & 0,4 & 0,9 & $-0,9$ & $-0,4$ & $-1,2$ & $-0,7$ & $-0,7$ & $-1,6$ & $-0,7$ & $-0,7$ & $-0,6$ & $-1,4$ \\
\hline
\end{tabular}

Fonte: ftp://ftpprd.ncep.noaa.gov/pub/cpc/wd52dg/data/indices/soi (em 11/05/2004). 
Tabela 2. Regiões de cultivo, estações meteorológicas, localização geográfica e épocas de semeadura de trigo no Paraná (IAPAR, 2002)

\begin{tabular}{|c|c|c|c|c|c|}
\hline $\begin{array}{l}\text { Região de } \\
\text { cultivo } \\
\end{array}$ & $\begin{array}{c}\text { Estação/ } \\
\text { Município }\end{array}$ & $\begin{array}{c}\text { Latitude } \\
\text { (S) }\end{array}$ & $\begin{array}{c}\text { Longitude } \\
\text { (W) }\end{array}$ & $\begin{array}{c}\text { Altitude } \\
\text { (m) }\end{array}$ & $\begin{array}{c}\text { Época de } \\
\text { Semeadura }\end{array}$ \\
\hline \multirow[t]{5}{*}{ Norte } & Ibiporã & $23^{0} 16^{\prime}$ & $51^{0} 01^{\prime}$ & 721 & \multirow{5}{*}{$\begin{array}{c}1^{\circ} \text { decêndio } \\
\text { de março }\end{array}$} \\
\hline & Apucarana & $23^{0} 30^{\prime}$ & $51^{0} 32^{\prime}$ & 746 & \\
\hline & Bandeirantes & $23^{0} 06^{\prime}$ & $50^{0} 21^{\prime}$ & 440 & \\
\hline & $\begin{array}{l}\text { Bela Vista do } \\
\text { Paraíso }\end{array}$ & $22^{0} 57^{\prime}$ & $51^{0} 12^{\prime}$ & 600 & \\
\hline & Londrina & $23^{0} 22^{\prime}$ & $51^{0} 10^{\prime}$ & 585 & \\
\hline \multirow[t]{3}{*}{ Noroeste } & Paranavaí & $23^{0} 08^{\prime}$ & $52^{0} 43^{\prime}$ & 480 & \multirow{3}{*}{$\begin{array}{c}2^{\circ} \text { decêndio } \\
\text { de maio }\end{array}$} \\
\hline & Umuarama & $23^{0} 44^{\prime}$ & $53^{0} 17^{\prime}$ & 480 & \\
\hline & Cianorte & $23^{0} 40^{\prime}$ & $52^{0} 35^{\prime}$ & 480 & \\
\hline \multirow{2}{*}{$\begin{array}{l}\text { Centro- } \\
\text { oeste }\end{array}$} & & $25^{0} 21^{\prime}$ & $51^{0} 30^{\prime}$ & 1058 & \multirow{2}{*}{$\begin{array}{c}2^{\circ} \text { decêndio } \\
\text { de maio }\end{array}$} \\
\hline & $\begin{array}{l}\text { Laranjeiras do } \\
\text { Sul }\end{array}$ & $25^{0} 25^{\prime}$ & $52^{0} 25^{\prime}$ & 880 & \\
\hline \multirow[t]{5}{*}{ Oeste } & Nova Cantu & $24^{0} 40^{\prime}$ & $52^{0} 34^{\prime}$ & 540 & \multirow{5}{*}{$\begin{array}{c}2^{o} \text { decêndio } \\
\text { de março }\end{array}$} \\
\hline & Palotina & $24^{0} 18^{\prime}$ & $53^{0} 55^{\prime}$ & 310 & \\
\hline & Cascavel & $24^{0} 57^{\prime}$ & $53^{0} 28$ & 750 & \\
\hline & $\begin{array}{l}\text { Quedas do } \\
\text { Iguaçu }\end{array}$ & $25^{0} 31^{\prime}$ & $53^{0} 01^{\prime}$ & 514 & \\
\hline & $\begin{array}{l}\text { São Miguel do } \\
\text { Iguaçu }\end{array}$ & $25^{0} 26^{\prime}$ & $54^{0} 22^{\prime}$ & 260 & \\
\hline \multirow[t]{3}{*}{ Sudoeste } & Francisco & $26^{0} 05^{\prime}$ & $53^{0} 04^{\prime}$ & 650 & \multirow{3}{*}{$\begin{array}{c}2^{\circ} \text { decêndio } \\
\text { de junho }\end{array}$} \\
\hline & Beltrão & & & & \\
\hline & Pato Branco & $26^{0} 07^{\prime}$ & $52^{0} 41^{\prime}$ & 700 & \\
\hline \multirow[t]{3}{*}{ Sul } & Clevelândia & $26^{0} 25^{\prime}$ & $52^{0} 21^{\prime}$ & 930 & \multirow{3}{*}{$\begin{array}{c}3^{\text {o }} \text { decêndio } \\
\text { de junho }\end{array}$} \\
\hline & Palmas & $26^{0} 29^{\prime}$ & $51^{0} 59^{\prime}$ & 1100 & \\
\hline & Lapa & $25^{0} 47^{\prime}$ & $49^{0} 46^{\prime}$ & 910 & \\
\hline
\end{tabular}




\section{RESULTADOS E DISCUSSÃO}

Os impactos dos eventos ENOS sobre o rendimento médio da cultura de trigo no Estado do Paraná foram avaliados separadamente nas seis regiões produtoras. Durante o período estudado (1976 a 2002) ocorreram 10 eventos EL Niño (EN) e 6 La Niña (LN), sendo que 11 anos foram considerados neutros (NE), sem manifestação do fenômeno.

Em todas regiões (menos a região sul) o rendimento médio regional mostrou tendência de aumento ao longo do período analisado. Eliminando-se essa tendência da série original de rendimento obteve-se uma nova série corrigida, da qual se extraiu a série de desvios do rendimento. Esses desvios foram então analisados quanto aos possíveis efeitos ENOS.

\subsection{Região Norte}

Em geral, a semeadura do trigo na região norte tem início a partir da primeira semana de abril e o ciclo da cultura varia de 120 a 140 dias, de acordo com as condições meteorológicas. Nessa região o rendimento médio era próximo de 0,8 $\mathrm{Mg} \mathrm{ha}^{-1}$ em 1976 e de 2,6 $\mathrm{Mg} \mathrm{ha}^{-1}$ em 2002 (Figura 3A). O incremento médio ponto-a-ponto (1976 a 2002) foi cerca de $0,055 \mathrm{Mg} \mathrm{ha}^{-1} \mathrm{ano}^{-1}$. 
A tendência tecnológica (TT), determinada pela inclinação da reta de regressão linear, indica incremento médio menor e igual a 0,037 $\mathrm{Mg} \mathrm{ha}^{-1} \mathrm{ano}^{-1}$. A média do rendimento real no período foi cerca de 1,045 $\mathrm{Mg} \mathrm{ha}^{-1}$ enquanto que sem a TT (produtividade corrigida) a média seria igual a 1,08 $\mathrm{Mg} \mathrm{ha}^{-1}$ (Figura 3B). Os desvios em relação a essa média corrigida mostram que não houve associação direta com a ocorrência de EN e LN (Figura 3C). Grandes desvios de rendimento ocorreram tanto em anos com EN como naqueles de LN e também em anos neutros.

Os maiores desvios negativos de rendimento ocorreram em 1977 (EN, -0,56 $\mathrm{Mg} \mathrm{ha}^{-1}$ ), 1996 (LN, -0,53 $\mathrm{Mg} \mathrm{ha}^{-1}$ ), 1999 (LN, -0,93 $\mathrm{Mg} \mathrm{ha}^{-1}$ ) e 2001(LN, -0,93 Mg ha $\left.{ }^{1}\right)$. Nesses anos houve excesso de chuva na fase de florescimento e no início da frutificação, mais ou menos aos 60 dias após a semeadura, início de junho. Alta umidade nessa fase causa chochamento dos grãos e facilita ataques de pragas e doenças.

A queda no rendimento em 1977 (EN) pode ser atribuída à ocorrência de chuvas no segundo e terceiro decêndios de junho, coincidindo com florescimento e início da frutificação, (Figura 4A). Em 1995 e 1999 (anos LN) a precipitação ocorreu no período de maturação e colheita (Figura 4B e 4C), podendo ter ocasionado a germinação dos grãos ainda na planta prejudicando a qualidade e dificultado a colheita (Silva, 1971; Mota, 1982).

Em 2001 (LN) as chuvas se concentraram no segundo decêndio de março (95 mm), e primeiro decêndio de abril (80 mm), e no segundo decêndio de junho, prolongando-se até o final deste mês. A alta umidade pode ter sido responsável pela maior queda de produtividade (-0,93 $\mathrm{Mg} \mathrm{ha}^{-1}$ ) da série nessa região (Figura 4D).

Os maiores desvios positivos de produtividade foram observados em 1984 (NE, +0,66 Mg ha-1), 1986 (EN, +0,44 Mg ha-1), 1987 (NE, +0,67 Mg ha-1), 1988 (LN, +0,45 $\mathrm{Mg} \mathrm{ha}^{-1}$ ), 2000 (LN, +0,40 $\mathrm{Mg} \mathrm{ha}^{-1}$ ) e $2002\left(\mathrm{NE},+0,50 \mathrm{Mg} \mathrm{ha}^{-1}\right.$ ). Nos cultivos de 1984, 1986 e 1988 as chuvas ocorreram em meados de abril, logo após a semeadura, e após o período de desenvolvimento vegetativo,houve baixa umidade, situação favorável para o período de frutificação, maturação e colheita (Figura 5 A, B e D).

Em 1987 houve déficit hídrico acentuado até abril atrasando a semeadura para o final de abril e início de maio, quando a condição de umidade do solo era 
favorável à germinação e desenvolvimento vegetativo. Com esse atraso a frutificação ocorreu a partir do início de julho, época em que as chuvas foram mais escassas, situação ideal para a maturação e a colheita dos grãos, sem perdas por excesso de umidade (Figura 5C).

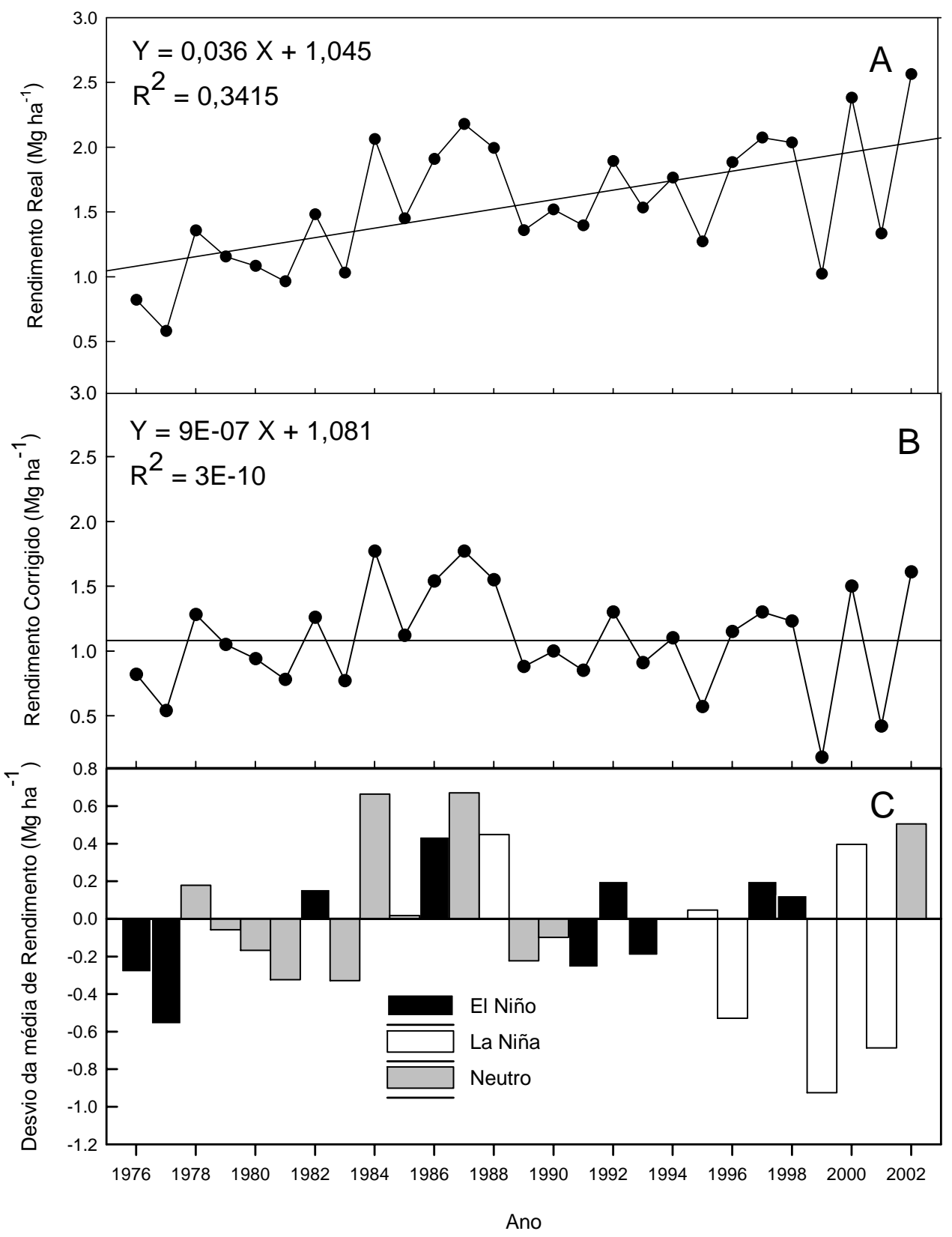

Figura 3- Série histórica original (A), corrigida (B), e desvios da média de rendimentos corrigidos (C) de trigo para a região norte do Paraná. 1976 a 2002 


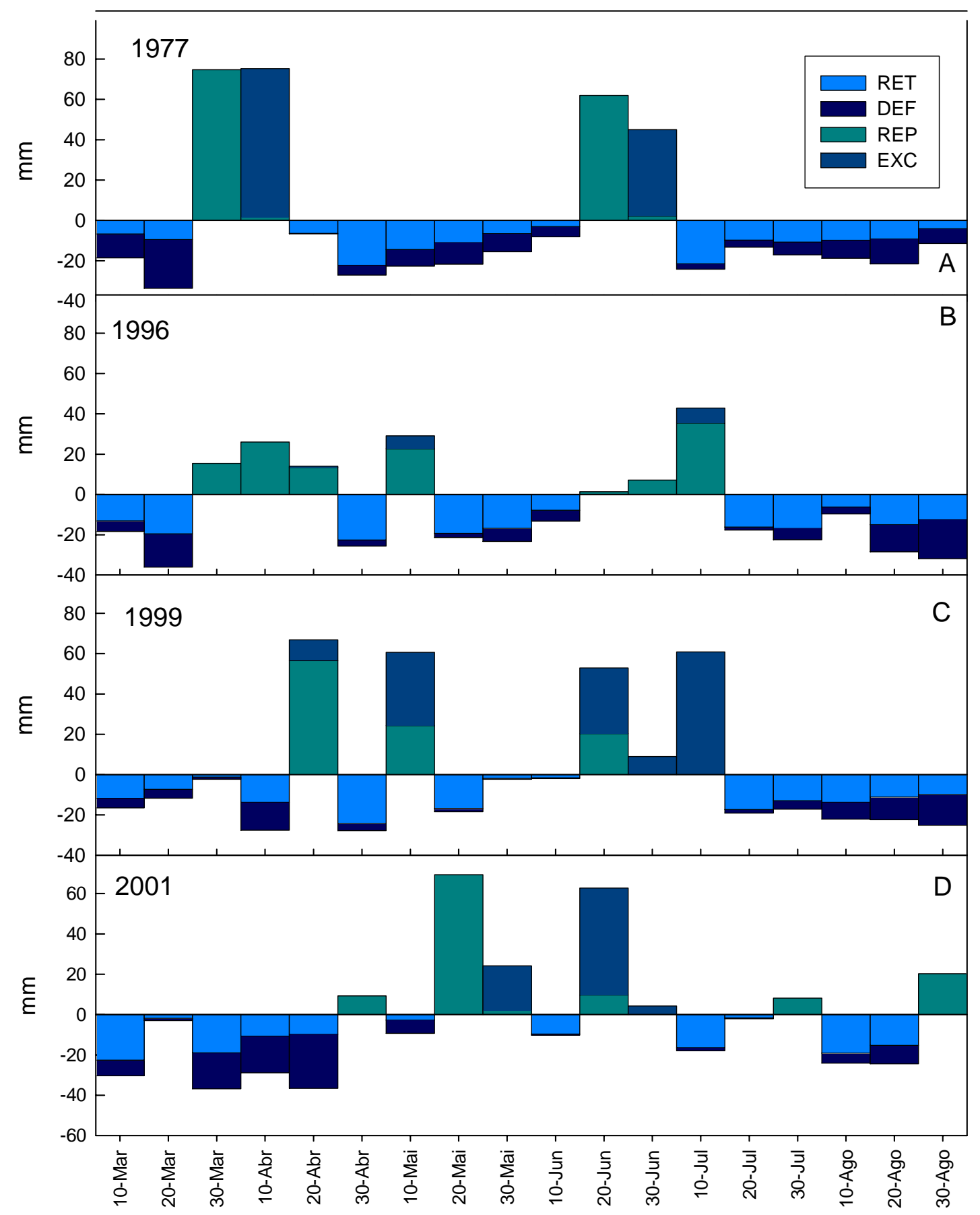

Decêndio

Figura 4- Balanço hídrico climatológico $(\mathrm{CAD}=100 \mathrm{~mm})$ na região norte do Paraná, durante o cultivo em anos de queda da produtividade 


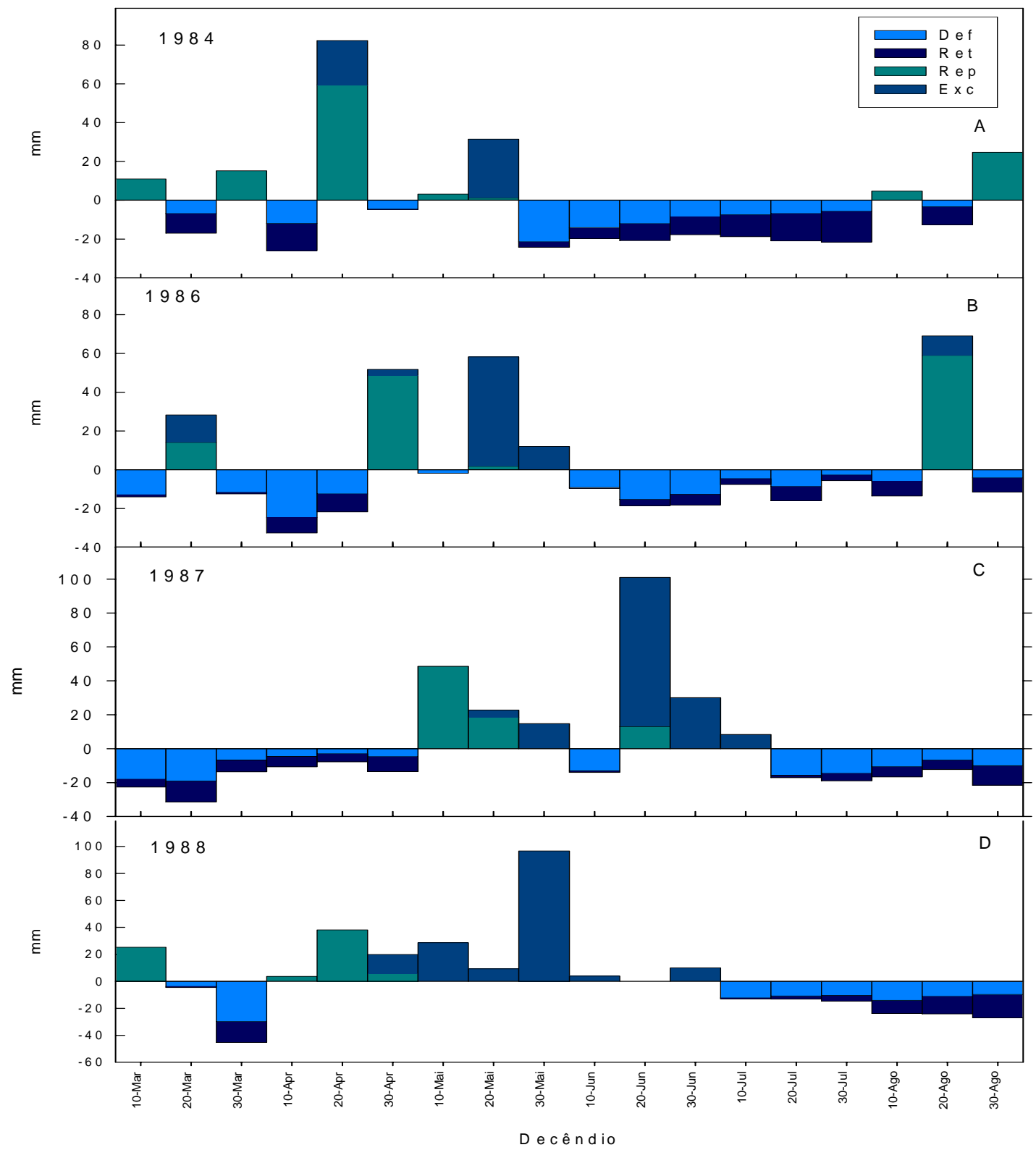

Figura 5- Balanço hídrico climatológico $(\mathrm{CAD}=100 \mathrm{~mm})$ na região norte do Paraná, durante o cultivo em anos de acréscimo a produtividade

Quanto ao IOS, durante o período de cultivo foram observados 17 valores mensais negativos e 10 valores positivos (Tabela 3). Dos 17 valores negativos, 10 ocorreram em anos de EN. Relacionando-se os valores de IOS e desvio de produtividade 
em anos de EN observou-se queda na produtividade em 1976, 1977, 1991 e 1993, e aumento em 1982, 1986, 1992, 1997 e 1998. Em 1994 não houve variação na produtividade. Em anos de LN ocorreram 4 valores positivos e 2 negativos de IOS, sendo que quando IOS negativos ocorreu queda na produtividade em 1995 e 2001 e quando IOS positivo houve acréscimo em 1988, 1996, 1999 e 2000.

Tabela 3. Sinal dos Valores mensais de Índice de Oscilação Sul (IOS) e desvio da produtividade de trigo na região norte do Paraná. 1976 a 2002

\begin{tabular}{lcll}
\hline \multicolumn{1}{c}{ Evento } & \multicolumn{1}{c}{$\begin{array}{c}\text { Valores de } \\
\text { IOS }\end{array}$} & \multicolumn{1}{c}{$\begin{array}{c}\text { Desvio de } \\
\text { produtividade }\end{array}$} & \multicolumn{1}{c}{$\begin{array}{c}\text { Anos de } \\
\text { ocorrência }\end{array}$} \\
\hline El Niño & 10 negativos & $\begin{array}{l}5 \text { positivos } \\
4 \text { negativos }\end{array}$ & $\begin{array}{l}1982,1986,1992,1997,1998 \\
1976,1977,1991,1993\end{array}$ \\
& & 1 nulo & 1994 \\
La Niña & 2 negativos & 2 negativos & 1995,2001 \\
& 4 positivos & 4 positivos & $1988,1996,1999,2000$ \\
& & & 1978,2002 \\
Neutro & 5 negativos & 2 positivos & $1980,1989,1990$ \\
& & 3 negativos & $1983,1985,1987$ \\
& 6 positivos & 3 positivos & $1979,1981,1984$ \\
\hline
\end{tabular}

\section{2 - Região Noroeste}

Na região noroeste a semeadura de trigo, tem início a partir do $2^{\circ}$ decêndio de maio, permanecendo a cultura no campo até meados de outubro, variando o ciclo de 120 a 140 dias, de acordo com as condições meteorológicas. O rendimento médio de grãos de determinado pelo ajuste indica incremento médio menor e igual a $0,034 \mathrm{Mg}$ $\mathrm{ha}^{-1} \mathrm{ano}^{-1}$ (Figura 6A). A média do rendimento no período foi cerca de 1,30 $\mathrm{Mg} \mathrm{ha}^{-1}$, 
enquanto que quando se retirou a tendência tecnológica esse rendimento passou a ser 0,88 $\mathrm{Mg} \mathrm{ha}^{-1}$ (Figura 6B).

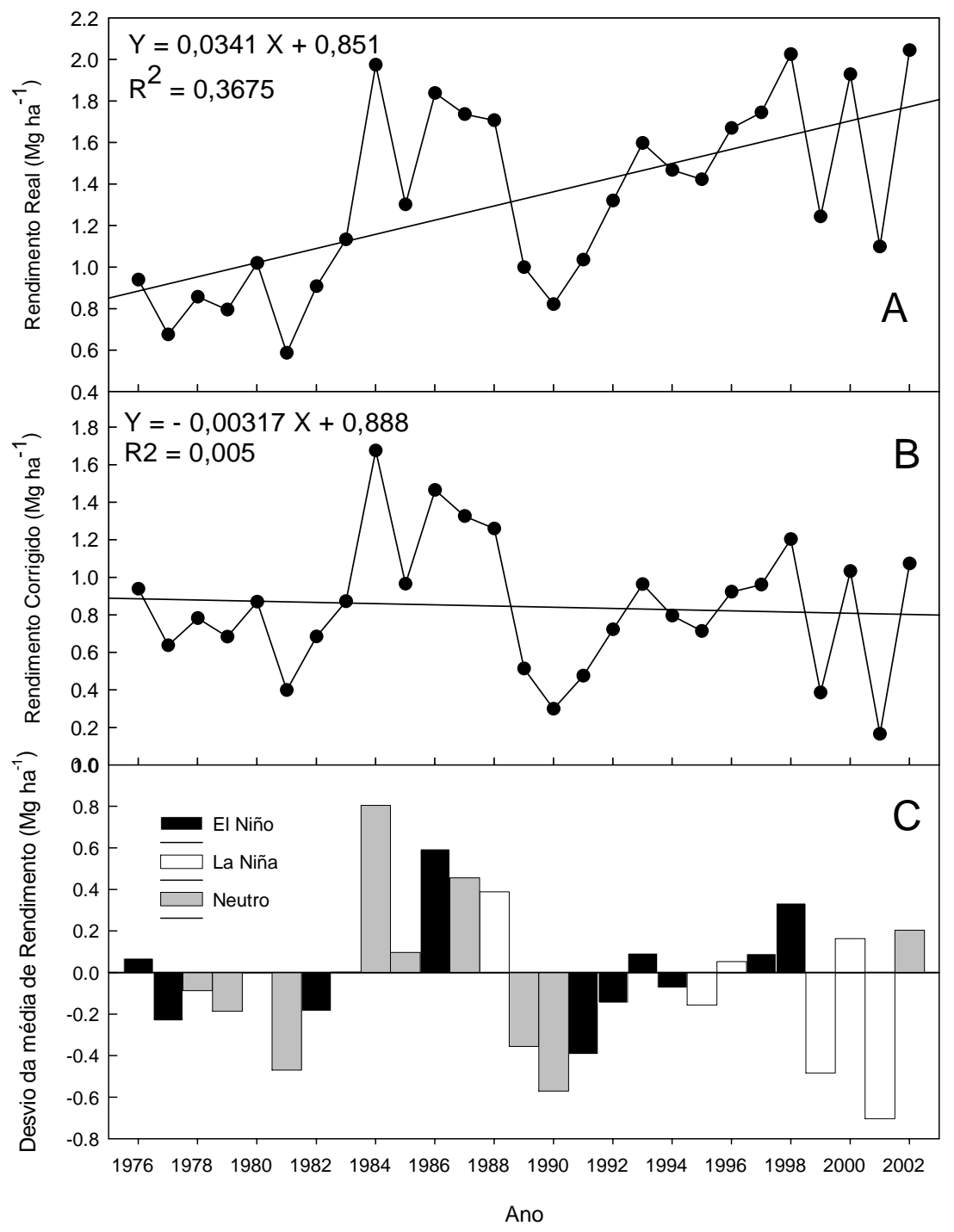

Figura 6- Série histórica original (A), corrigida (B) e desvios da média de rendimento corrigidos (C) de trigo para a região noroeste do Paraná, de 1976 a 2002 
Nessa região também não houve associação direta entre os desvios de produtividade e a ocorrência de EN/LN. Grandes desvios de produtividade ocorreram tanto em anos de EN como de LN e também em anos neutros (NE). Em anos de EN foi observado tanto desvio positivo (+0,60 $\mathrm{Mg} \mathrm{ha}^{-1}$ ) em 1986, como negativo (-0,40 Mg ha1) em 1991.

Em anos NE houve acréscimo em $1984\left(+0,80 \mathrm{Mg} \mathrm{ha}^{-1}\right)$, enquanto que em $1981\left(-0,47 \mathrm{Mg} \mathrm{ha}^{-1}\right), 1990\left(-0,57 \mathrm{Mg} \mathrm{ha}^{-1}\right)$ e $2001\left(-0,70 \mathrm{Mg} \mathrm{ha}^{-1}\right)$ ocorreram as maiores quedas (Figura 6C).

Em 1984 (NE) houve o maior aumento na produtividade durante o período observado, cerca de $+0,80 \mathrm{Mg} \mathrm{ha}^{-1}$. O balanço hídrico climatológico mostra que as chuvas no $1^{\circ}$ e $2^{\circ}$ decêndio de maio favoreceram a semeadura. No $3^{\circ}$ decêndio de maio e no $1^{0}$ de junho o solo já se encontrava em condição ideal. Entre o $1^{0}$ decêndio de junho e o $1^{0}$ decêndio de setembro, o solo permaneceu em condição de baixa umidade e até com deficiência hídrica, condição favorável ao desenvolvimento da cultura (Figura 7A).

Em 1986 (EN) houve desvio positivo de $+0,60 \mathrm{Mg} \mathrm{ha}^{-1}$. As chuvas ocorreram em maio, seguindo os próximos meses com baixa umidade até $2^{\circ}$ decêndio de agosto (Figura 7B). Como em 1984, essa situação de baixa umidade favoreceu o aumento da produtividade.

Em 1990 (NE) a queda foi em torno de $-0,57 \mathrm{Mg} \mathrm{ha}^{-1}$. O balanço hídrico climatológico indica que esse foi ano chuvoso durante o período de cultivo, sendo mais chuvoso em setembro, na fase de maturação (Figura 8A). A alta umidade contribuiu para infestação de pragas e doenças e também para o atraso da colheita.

Em 1999 as chuvas se concentraram no mês de junho, logo após a semeadura e início da germinação. Após esse período chuvoso o solo permaneceu em condição de seca até a colheita (Figura 8B).

Em 2001, a alta umidade na época de semeadura (maio) e no período de germinação (junho) pode ter contribuído para a ocorrência de doenças. A ocorrência de chuva no final do ciclo, pode ter afetado ainda a fase de colheita (Figura 8C).

Durante o período analisado foram observados 17 valores mensais negativos e 10 valores positivos de IOS (Tabela 4). Em todos os anos de EN registrou-se valores 
negativos de IOS com acréscimo a produtividade em 5 anos (1976, 1986, 1993, 1997 e 1998) e queda em 5 anos (1977, 1982, 1991, 1992 e 1994). Foram observados valores positivos de IOS em 66,6\% dos anos de LN, com aumento na produtividade em 1988, 1996 e 2000, e queda em 1999.

Nos anos NE verificou-se 5 valores negativos e 6 positivos de IOS. Valores negativos foram associados a ganho na produtividade apenas em 2002 e queda em 1978, 1989 e 1990. Em 1980 não houve desvio na produtividade. Em anos com valores positivos houve aumento na produtividade em 1983, 1984, 1985 e 1987 e queda em 1979 e 1981.

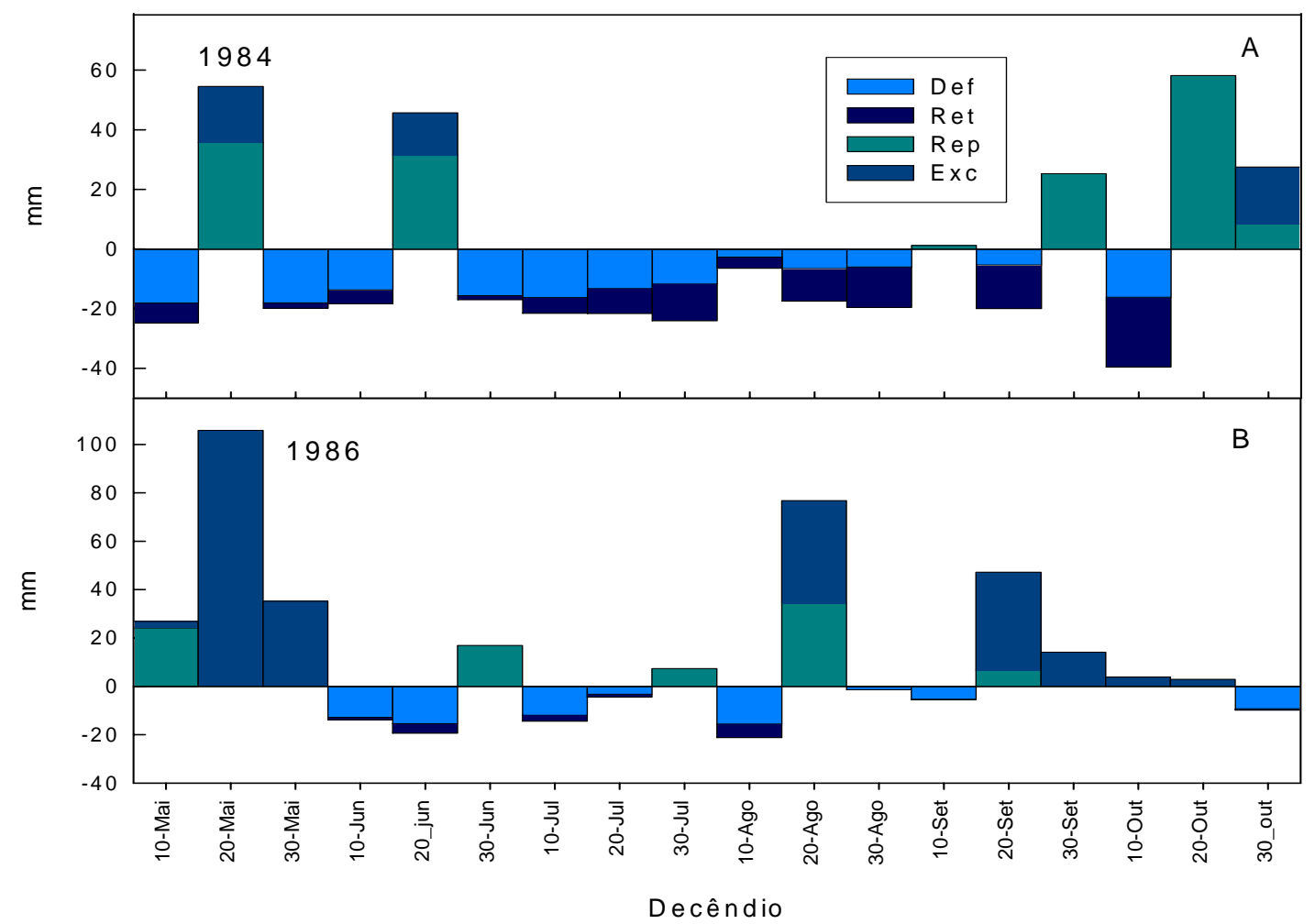

Figura 7- Balanço hídrico climatológico $(\mathrm{CAD}=100 \mathrm{~mm})$ para a região noroeste do Paraná, durante o cultivo em anos de acréscimo da produtividade 


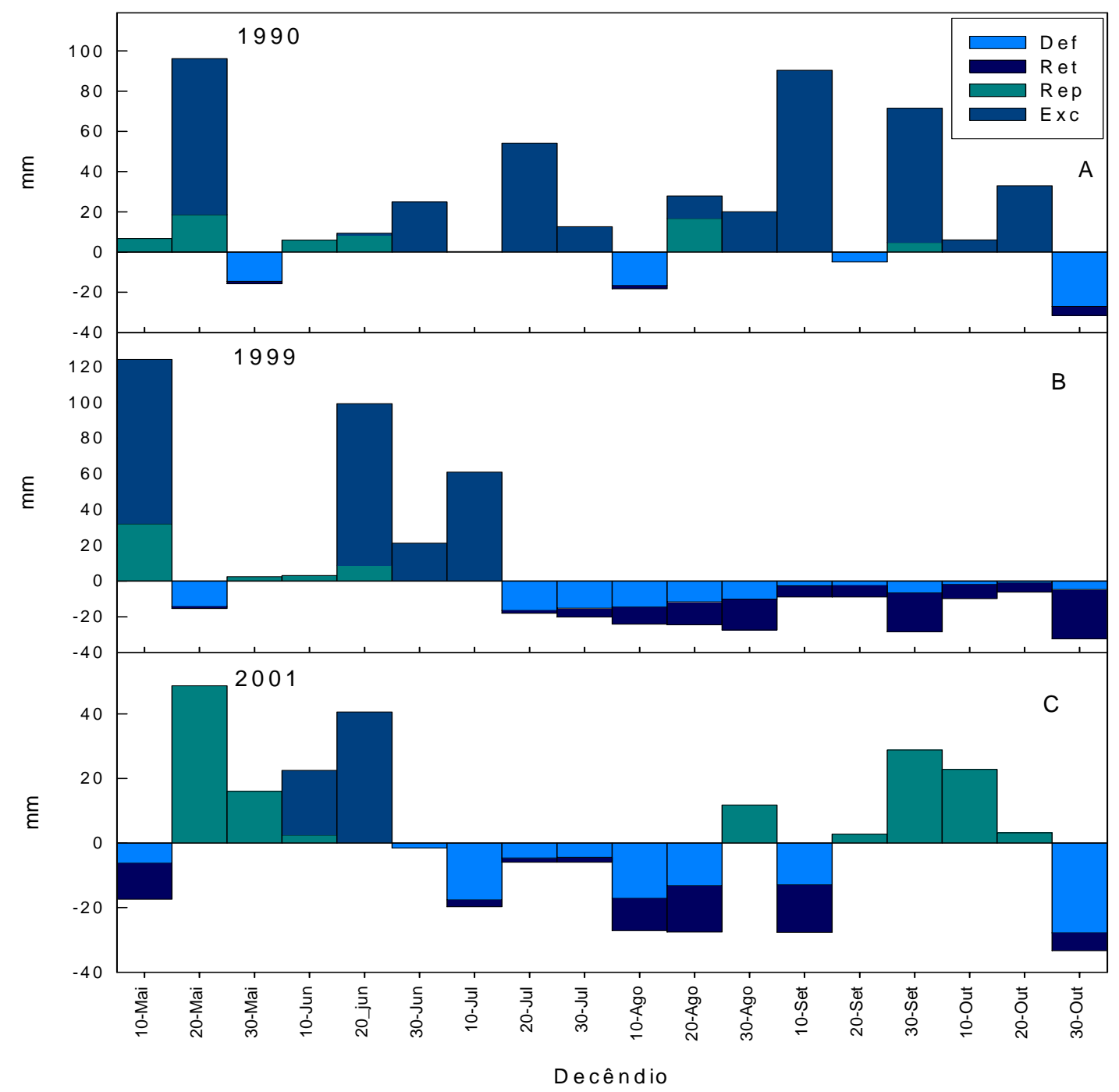

Figura 8- Balanço hídrico climatológico $(\mathrm{CAD}=100 \mathrm{~mm})$ para a região noroeste do Paraná, durante o cultivo em anos de queda da produtividade 
Tabela 4. Sinal de Valores mensais de Índice de Oscilação Sul (IOS) e desvio da produtividade de trigo na região noroeste do Paraná. 1976 a 2002

\begin{tabular}{|c|c|c|c|}
\hline Evento & $\begin{array}{c}\text { Valores de } \\
\text { IOS }\end{array}$ & $\begin{array}{c}\text { Desvio de } \\
\text { produtividade }\end{array}$ & $\begin{array}{c}\text { Anos de } \\
\text { Ocorrência }\end{array}$ \\
\hline El Niño & 10 negativos & $\begin{array}{l}5 \text { positivos } \\
5 \text { negativos }\end{array}$ & $\begin{array}{l}\text { 1976, 1986, 1993, 1997, } 1998 \\
\text { 1977, 1982, 1991, 1992, } 1994\end{array}$ \\
\hline La Niña & $\begin{array}{l}2 \text { negativos } \\
4 \text { positivos }\end{array}$ & $\begin{array}{l}2 \text { negativos } \\
3 \text { positivos } \\
1 \text { negativo }\end{array}$ & $\begin{array}{l}\text { 1995, } 2001 \\
\text { 1988, 1996, } 2000 \\
1999\end{array}$ \\
\hline Neutro & 5 negativos & $\begin{array}{l}1 \text { positivo } \\
3 \text { negativos } \\
1 \text { nulo }\end{array}$ & $\begin{array}{l}2002 \\
1978,1989,1990 \\
1980\end{array}$ \\
\hline & 6 positivos & $\begin{array}{l}4 \text { positivos } \\
2 \text { negativos }\end{array}$ & $\begin{array}{l}\text { 1983, 1984, 1985, } 1987 \\
\text { 1979, } 1981\end{array}$ \\
\hline
\end{tabular}

\section{3- Região Sudoeste}

A semeadura nessa região se dá a partir do $2^{0}$ decêndio de junho, permanecendo a cultura no campo até fim de outubro e meados de novembro, com ciclo variando de 120 a 140 dias. O rendimento médio era em torno de 0,85 $\mathrm{Mg} \mathrm{ha}^{-1}$ em 1976, e 2,0 $\mathrm{Mg} \mathrm{ha}^{-1}$ em 2002 (Figura 9A). O incremento médio ponto-a-ponto nesse período foi $0,055 \mathrm{Mg} \mathrm{ha}^{-1} \mathrm{ano}^{-1}$. A TT determinada pelo ajuste estatístico indica incremento médio igual a 0,04 $\mathrm{Mg} \mathrm{ha}^{-1} \mathrm{ano}^{-1}$. A média do rendimento no período foi igual a 1,35 Mg ha ${ }^{-1}$, enquanto que sem a TT foi 0,70 $\mathrm{Mg} \mathrm{ha}^{-1}$ (Figura 9B).

Também não houve associação direta entre desvios de produtividade e ocorrência de EN. Ocorreu queda na produtividade em 83,3\% do anos com LN. Grandes 
desvios de rendimento foram em anos de EN, de LN e NE (Figura 9C). Os maiores desvios negativos ocorreram em 1979 (NE), 1991 (EN) e 1997 (EN), e 1998 (EN) e 1999 (LN); e os maiores desvios positivos foram em 1983 (NE), 1994 (EN) e 1995 $(\mathrm{LN})$.

Em 1979 (NE) as chuvas foram freqüentes a partir de julho e se estenderam até o $2^{0}$ decêndio de novembro. Choveu $960 \mathrm{~mm}$ nesse período, ocasionando alta umidade o que contribuiu para queda de $-0,55 \mathrm{Mg} \mathrm{ha}^{-1}$ na produtividade (Figura $10 \mathrm{~A}$ ).

Em 1991 (EN), a partir do $2^{\circ}$ decêndio de agosto, ocorreram chuvas que se estenderam até o $1^{0}$ decêndio de setembro, coincidindo com florescimento e início da frutificação, causando queda de flores, afetando a frutificação. Também choveu desde o $3^{0}$ decêndio de setembro até o $3^{0}$ decêndio de novembro (maturação e colheita) favorecendo a ocorrência de pragas e doenças. Devido à alta umidade houve germinação de grãos ainda na planta, ocasionando queda na produtividade e na qualidade (Figura 10 B).

Em 1997 e 1998 (EN) a situação de umidade foi semelhante com chuva durante todo o período de cultivo. Em 1997, durante o $1^{\circ}$ decêndio de agosto choveu 240 $\mathrm{mm}$, e a partir do $1^{\circ}$ decêndio de setembro as chuvas foram freqüentes até dezembro acumulando 893 mm (Figura 11A). Em 1998 as chuvas foram mais freqüentes a partir do $2^{\circ}$ decêndio de agosto $(170 \mathrm{~mm})$ e se estenderam até início de novembro totalizando $1002 \mathrm{~mm}$. A alta umidade nos dois anos foi determinante da queda de -0,55 $\mathrm{Mg} \mathrm{ha}^{-1} \mathrm{em}$ 1997, e de -0,26 Mg ha-1 em 1998 (Figura 11B). Em 1999 (LN) a queda na produtividade foi semelhante a 1998 (-0,26 Mg ha $\left.{ }^{-1}\right)$. Houve chuva em junho e julho, contribuindo para o ataque de pragas e doenças logo após a emergência. O período seguinte foi seco, mas no $2^{\circ}$ decêndio de setembro choveu $80 \mathrm{~mm}$, e esse período chuvoso se prolongou até $2^{\circ}$ decêndio de novembro (Figura 11C).

Todos os anos com queda na produtividade tiveram chuvas de setembro a outubro, evidenciando o efeito negativo da alta umidade no final do ciclo da cultura.

Os maiores incrementos no rendimento $\left(+0,5 \mathrm{Mg} \mathrm{ha}^{-1}\right)$ foram observados em 1983 (NE), 1994 (EN) e em 1995 (LN). Em 1983 choveu 450 mm no 1º decêndio de julho, fase de estabelecimento da cultura. Seguiu-se um período mais seco com pouca ou 
nenhuma chuva até meados de setembro. As chuvas foram suficientes para estabelecimento e desenvolvimento da cultura sem causar prejuízos por seca. A partir de setembro houve chuva, porém em quantidade insuficiente para causar danos na fase de maturação e colheita. Essas condições meteorológicas são as ideais para a triticultura (Figura $12 \mathrm{~A}$ ).

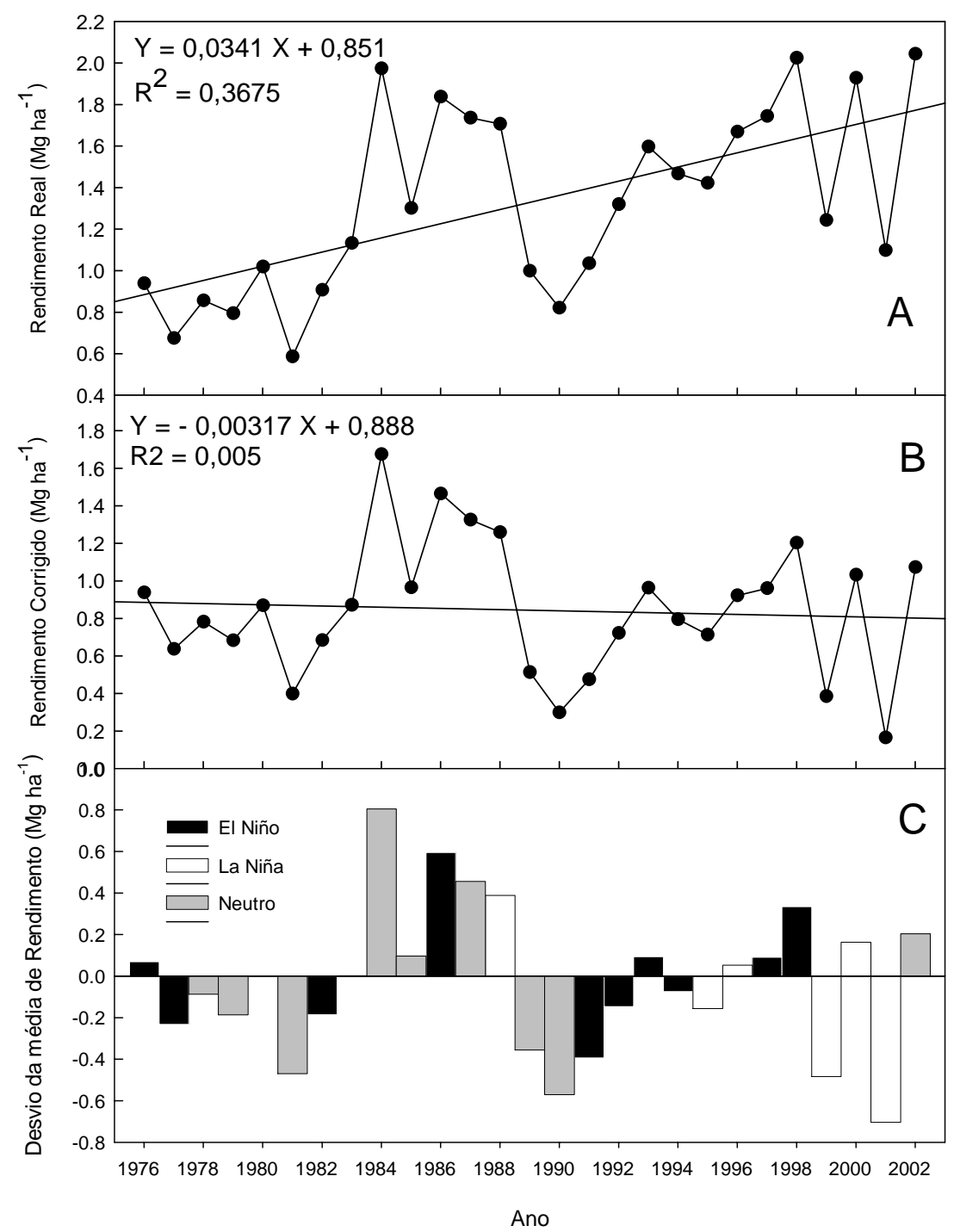

Figura 9- Série histórica original (A), corrigida (B) e desvios da média da produtividade corrigida (C) de trigo para a região sudoeste do Paraná, de 1976 a 2002 


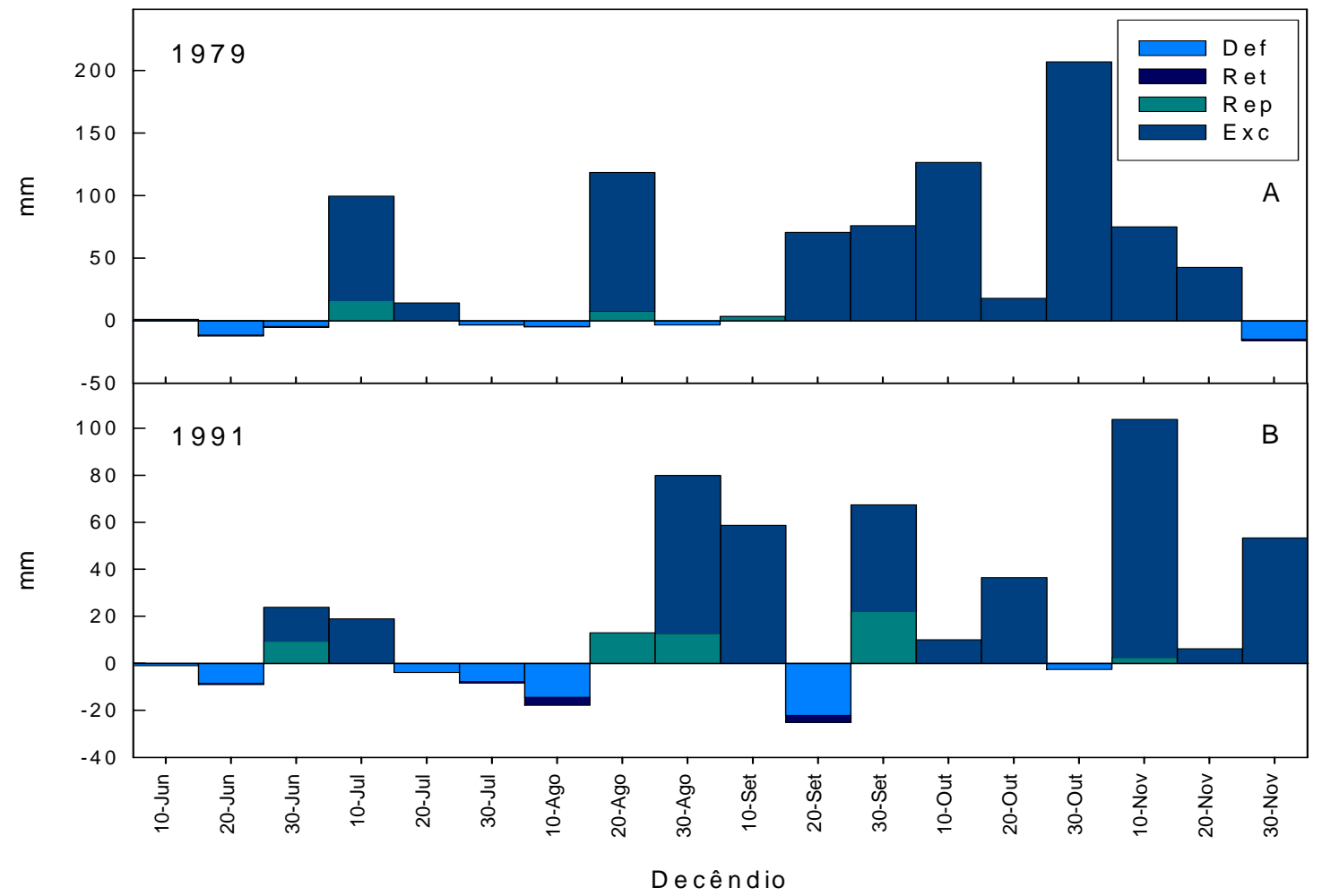

Figura 10- Balanço hídrico climatológico $(\mathrm{CAD}=100 \mathrm{~mm})$ para a região sudoeste do

Paraná, durante o cultivo em anos de queda da produtividade

Em 1994 ocorreu o maior desvio positivo na produtividade dessa região, cerca de $+0,55 \mathrm{Mg} \mathrm{ha}^{-1}$. Nesse ano as chuvas ocorreram no início do ciclo, e devido à condição mais seca que se seguiu, o ciclo foi reduzido e a colheita adiantada, não sendo prejudicada pelas chuvas a partir de outubro (Figura $12 \mathrm{~B}$ ).

Em 1995, no $3^{\circ}$ decêndio de setembro choveu $213 \mathrm{~mm}$ e as chuvas continuaram até final de outubro, porém em menor quantidade (cerca de $70 \mathrm{~mm}$ por decêndio), e não causaram danos à cultura (Figura 12 C).

Foram observados 17 valores mensais negativos e 10 valores positivos de IOS no período de cultivo dessa região (Tabela 5). Ocorreram 10 eventos EN e todos com valores negativos de IOS. Desses em 4 houve acréscimo da produtividade (1982, 1986, 1992, 1993 e 1994), e em 6 houve queda (1976, 1977, 1986, 1991, 1997 e 1998). Em anos de LN os valores de IOS foram positivos em 4 anos, com queda na 
produtividade em todos eles (1988, 1996, 1999 e 2000), e valores negativos em 2 anos, com acréscimo em 1995 e queda de produtividade em 2001. Em anos NE houve 5 valores negativos e 6 positivos de IOS. Dos anos com IOS negativos, a produção aumentou em 3 deles (1989, 1990 e 2002), e caiu em 1978. Em 1980 não houve alteração na produtividade.

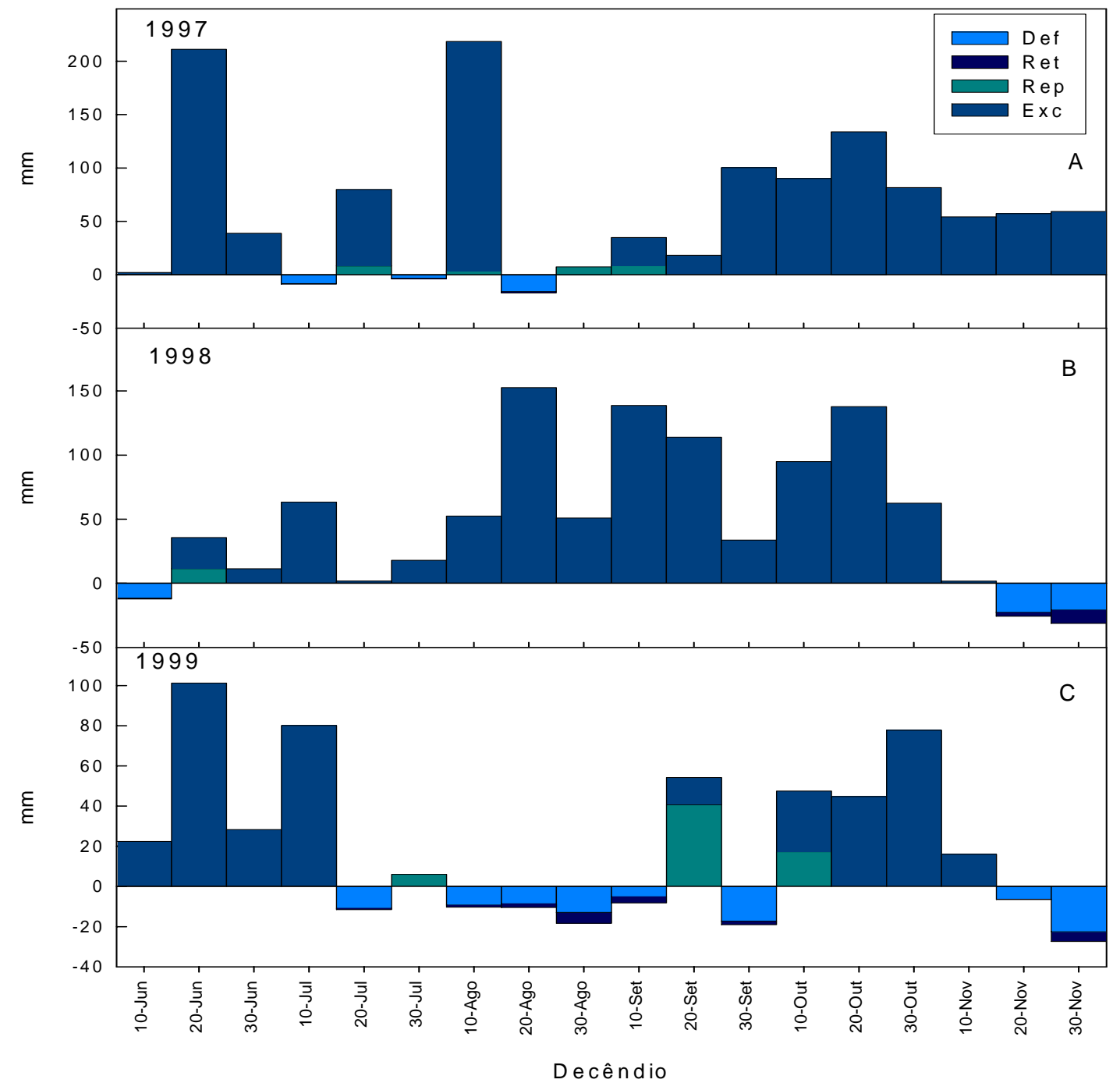

Figura 11- Balanço hídrico climatológico $(\mathrm{CAD}=100 \mathrm{~mm})$ para a região sudoeste do Paraná, durante o cultivo em anos de queda da produtividade 


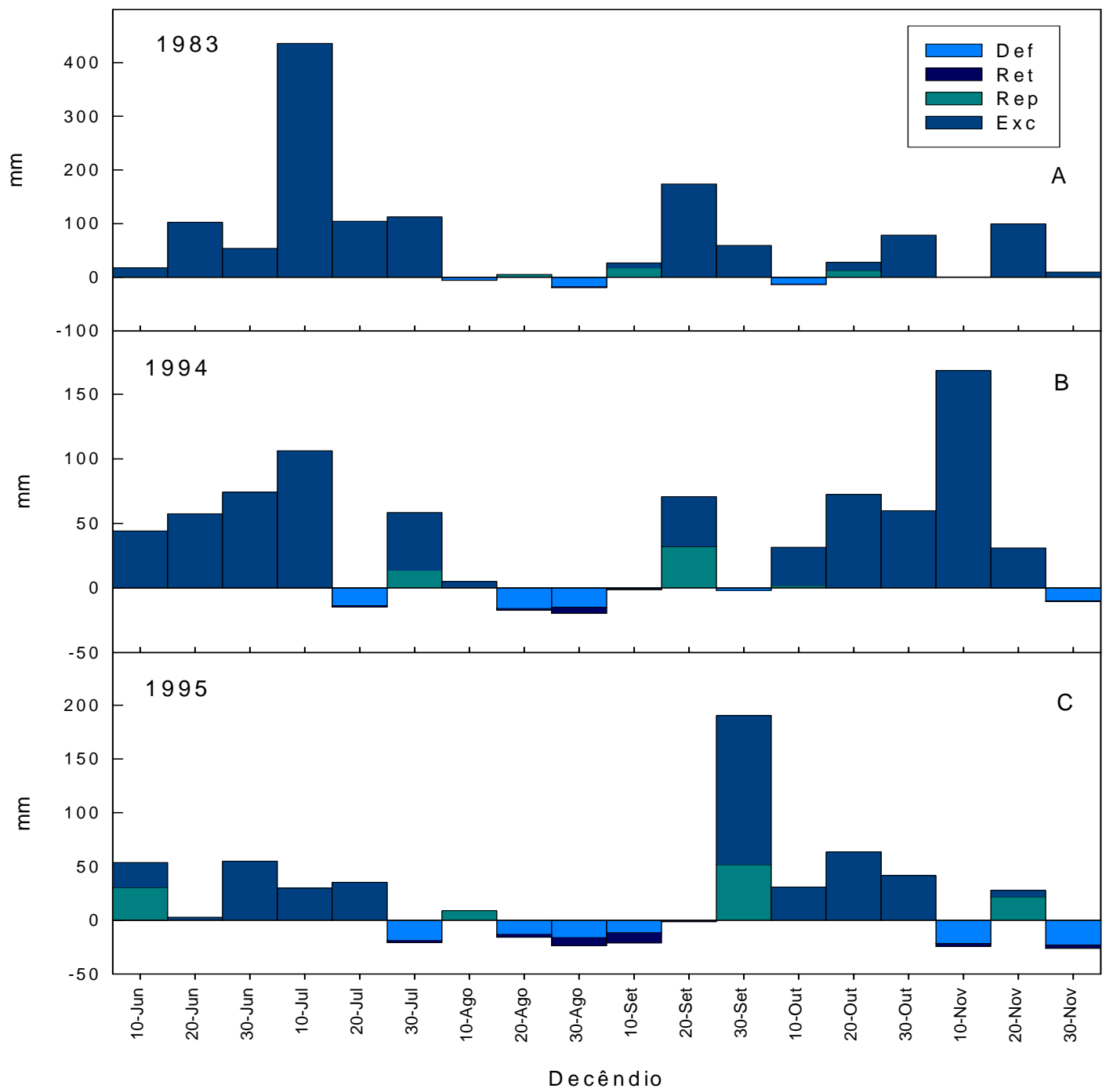

Figura 12- Balanço hídrico climatológico $(\mathrm{CAD}=100 \mathrm{~mm})$ para a região sudoeste do Paraná, durante o cultivo em anos com acréscimo a produtividade

Observando os valores positivos notou-se aumento na produtividade em 1983, 1984, 1985,e 1987, e queda em 1979 e 1981. Em anos NE, independente de IOS, houve aumento na produtividade na maioria dos casos. Nessa região, os EN coincidiram com valores negativos de IOS, e LN com valores positivos. Em anos de LN observou-se queda na produtividade na maioria dos anos (83,3\%). 
Tabela 5. Sinal dos Valores mensais de Índice de Oscilação Sul (IOS) e desvio da produtividade de trigo na região sudoeste do Paraná de 1976 a 2002

\begin{tabular}{|c|c|c|c|}
\hline Evento & $\begin{array}{c}\text { Valores de } \\
\text { IOS }\end{array}$ & $\begin{array}{c}\text { Desvio de } \\
\text { produtividade }\end{array}$ & $\begin{array}{c}\text { Anos de } \\
\text { Ocorrência }\end{array}$ \\
\hline \multirow[t]{2}{*}{ El Niño } & 10 negativos & 4 positivos & 1982, 1992, 1993, 1994 \\
\hline & & 6 negativos & $\begin{array}{l}\text { 1976, 1977, 1986,1991, } \\
\text { 1997, } 1998\end{array}$ \\
\hline \multirow[t]{3}{*}{ La Niña } & 4 positivos & 4 negativos & 1988, 1996, 1999, 2000 \\
\hline & 2 negativos & 1 positivo & 1995 \\
\hline & & 1 negativo & 2001 \\
\hline \multirow[t]{5}{*}{ Neutro } & 6 positivos & 4 positivos & 1983, 1984, 1985, 1987 \\
\hline & & 2 negativos & 1979, 1981 \\
\hline & 5 negativos & 3 positivos & 1989, 1990, 2002 \\
\hline & & 1 negativos & 1978 \\
\hline & & 1 nulo & 1980 \\
\hline
\end{tabular}

\section{4- Região Centro-Oeste}

A semeadura nessa região tem início a partir do $3^{0}$ decêndio de maio e a cultura permanece no campo até meados de outubro, variando o ciclo de 120 a 140 dias de acordo com as condições meteorológicas. O rendimento médio foi em torno de 0,9 $\mathrm{Mg} \mathrm{ha}^{-1}$ em 1976, e 2,3 $\mathrm{Mg} \mathrm{ha}^{-1}$ em 2002. O incremente médio ponto-a-ponto foi em torno de 0,06 $\mathrm{Mg} \mathrm{ha}^{-1} \mathrm{ano}^{-1}$. A TT, determinada estatisticamente, indica incremento médio menor e igual a $0,039 \mathrm{Mg} \mathrm{ha}^{-1}$ ano $^{-1}$ (Figura $13 \mathrm{~A}$ ). A média do rendimento de grãos no período foi 1,60 $\mathrm{Mg} \mathrm{ha}^{-1}$, e quando se retirou a TT a média caiu para 0,97 Mg ha $^{-1}$ (Figura 13 B). 
Nessa região houve associação direta entre ocorrência de EN e tendência a queda na produtividade. De 10 anos com EN, 7 apresentaram queda na produtividade. Em anos com LN não foi encontrada relação com desvios de produtividade. Houve acréscimo em 1995 e 1996, queda em 1999, 2000 e 2001, e em 1988 não houve desvio na produtividade (Figura $13 \mathrm{C}$ ).

Os maiores desvios negativos de produtividade foram observados em 1984 e 1995, e positivos em 1977, 1989, 1992 e 2001. Analisando o balanço hídrico climatológico de cada ano foi possível relacionar os desvios observados com as condições meteorológicas durante o período.

Em 1977 (EN) e 1984 (NE) foram observadas situações semelhantes de ocorrência de chuva, coincidindo épocas de maior e menor umidade. No entanto em relação à produtividade observou-se que apesar das mesmas condições de umidade, em 1977 ocorreu queda de -0,44 $\mathrm{Mg} \mathrm{ha}^{-1}$ (Figura 14 A) e em 1984 houve acréscimo de +0,71 Mg ha ${ }^{-1}$ (Figura $15 \mathrm{~A}$ ). Logo, a produtividade nesses dois anos não pode ser relacionada somente a fatores meteorológicos.

Em 1989 (NE) a queda na produtividade foi -0,60 $\mathrm{Mg} \mathrm{ha}^{-1}$ e, de acordo com o balanço hídrico, ocorreu chuva $(162 \mathrm{~mm})$ por volta dos 60 dias após a semeadura, o que pode ter afetado o florescimento. Houve alta umidade a partir do $3^{0}$ decêndio de agosto coincidindo com a maturação e início da colheita. No período de cultivo as épocas de chuva coincidiram com fases em que a cultura se encontrava sensível a alta umidade (Figura $14 \mathrm{~B}$ ).

Em 1992 (EN) houve queda de -0,60 $\mathrm{Mg} \mathrm{ha}^{-1}$ na produtividade. Ocorreu alta umidade no período de semeadura, cerca de $350 \mathrm{~mm}$. Durante todo o período de cultivo ocorreram chuvas menores, de 40 a 85 mm por decêndio, colaborando para a infestação de pragas e doenças afetando a produtividade (Figura $14 \mathrm{C}$ ).

Em 2001 (LN) a queda foi de $-0,63 \mathrm{Mg} \mathrm{ha}^{-1}$. Pelo balanço hídrico climatológico nota-se que o período de cultivo foi úmido (Figura 14 D).

Em 1995 (LN) houve acréscimo de $+0,53 \mathrm{Mg} \mathrm{ha}^{-1}$ na produtividade. No início do cultivo as chuvas foram escassas e, a partir do $3^{0}$ decêndio de setembro, se 
intensificaram. Porém, devido à baixa umidade nos meses anteriores, o ciclo foi reduzido e a umidade no final do ciclo não afetou a colheita (Figura 15 B).

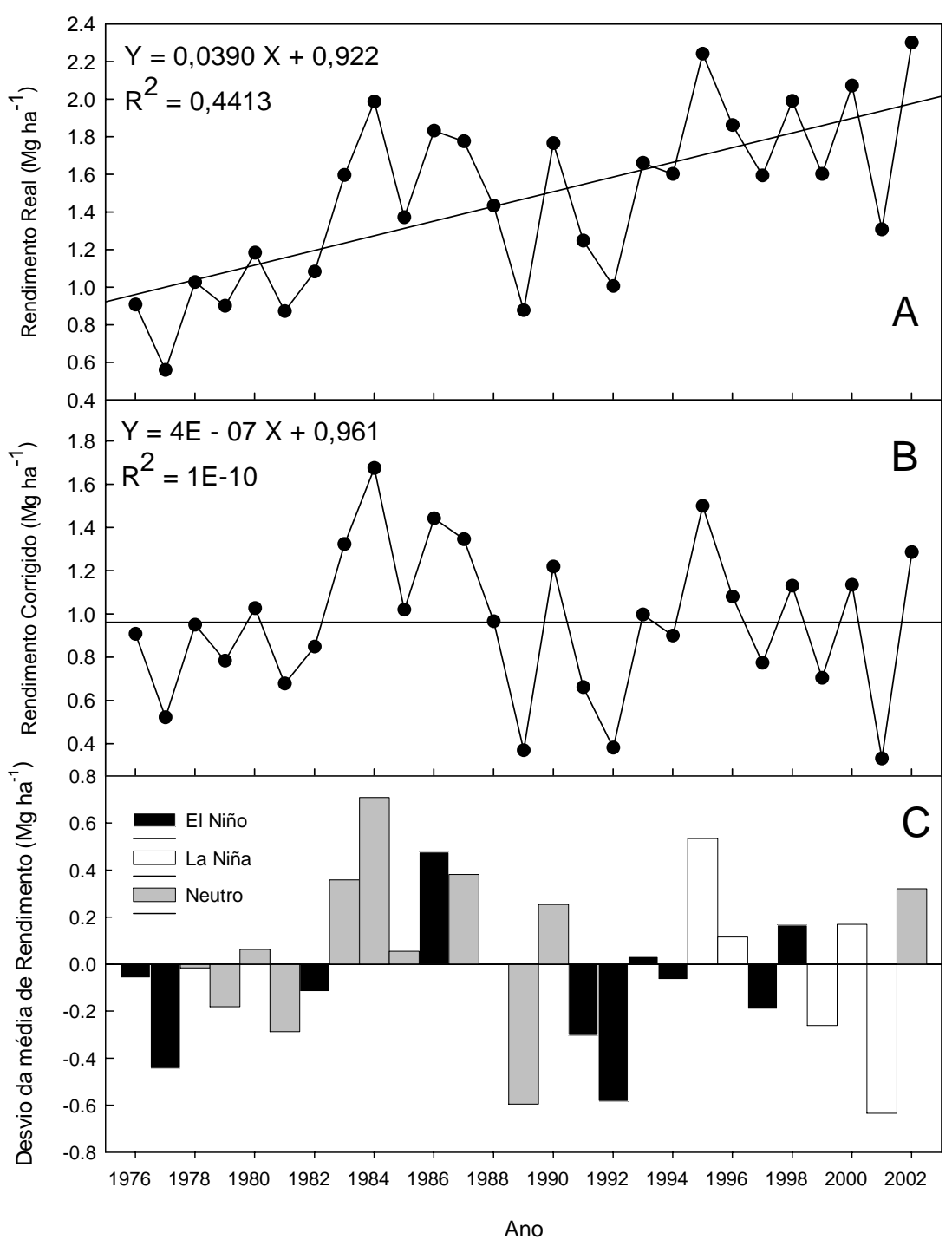

Figura 13- Série histórica original (A), corrigida (B) e desvios da média dos rendimentos corrigidos (C) de trigo para a região centro-oeste do Paraná, de 1976 a 2002 


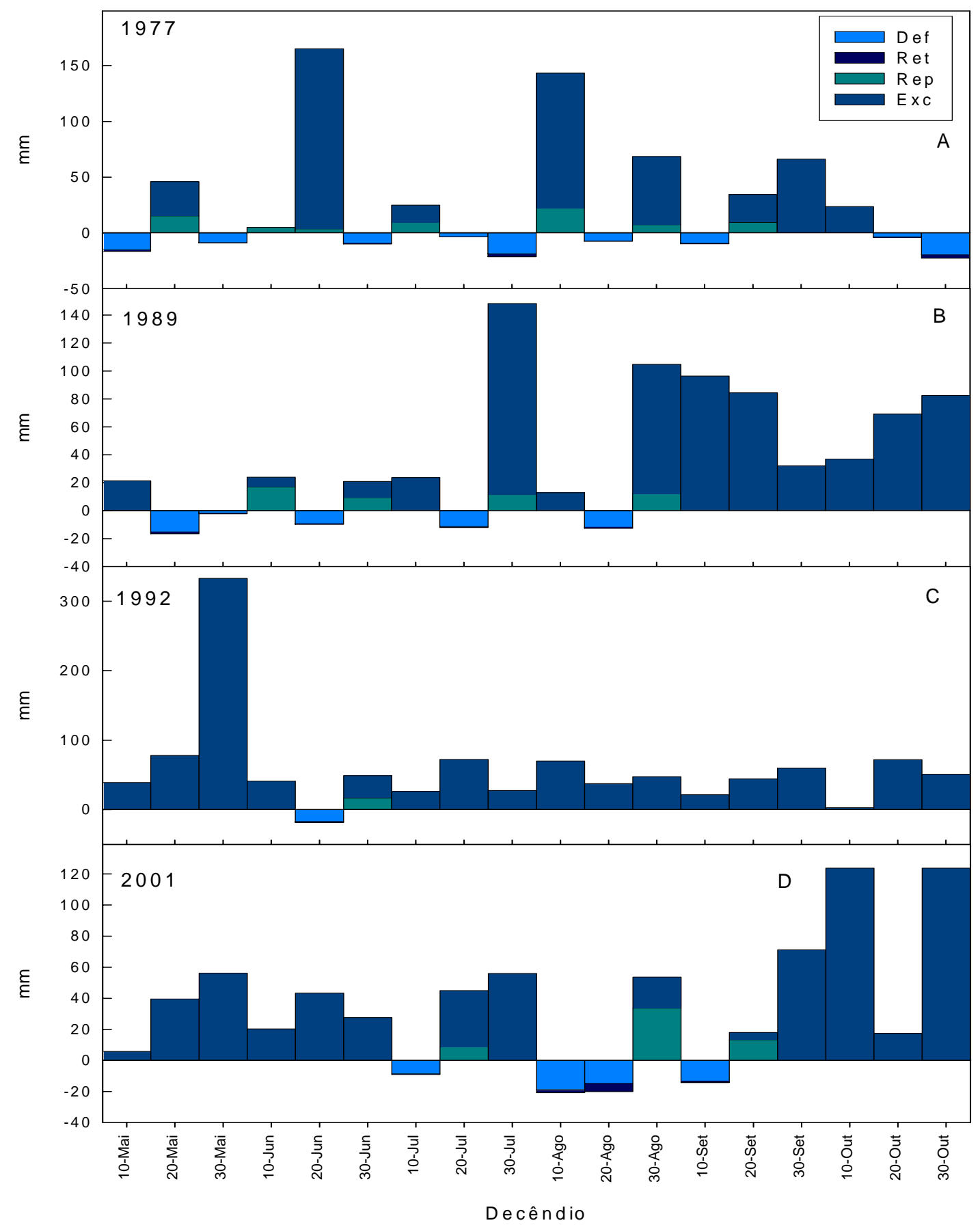

Figura 14- Balanço hídrico climatológico $(\mathrm{CAD}=100 \mathrm{~mm})$ para a região centro-oeste do Paraná, período de cultivo em anos de queda de produtividade 


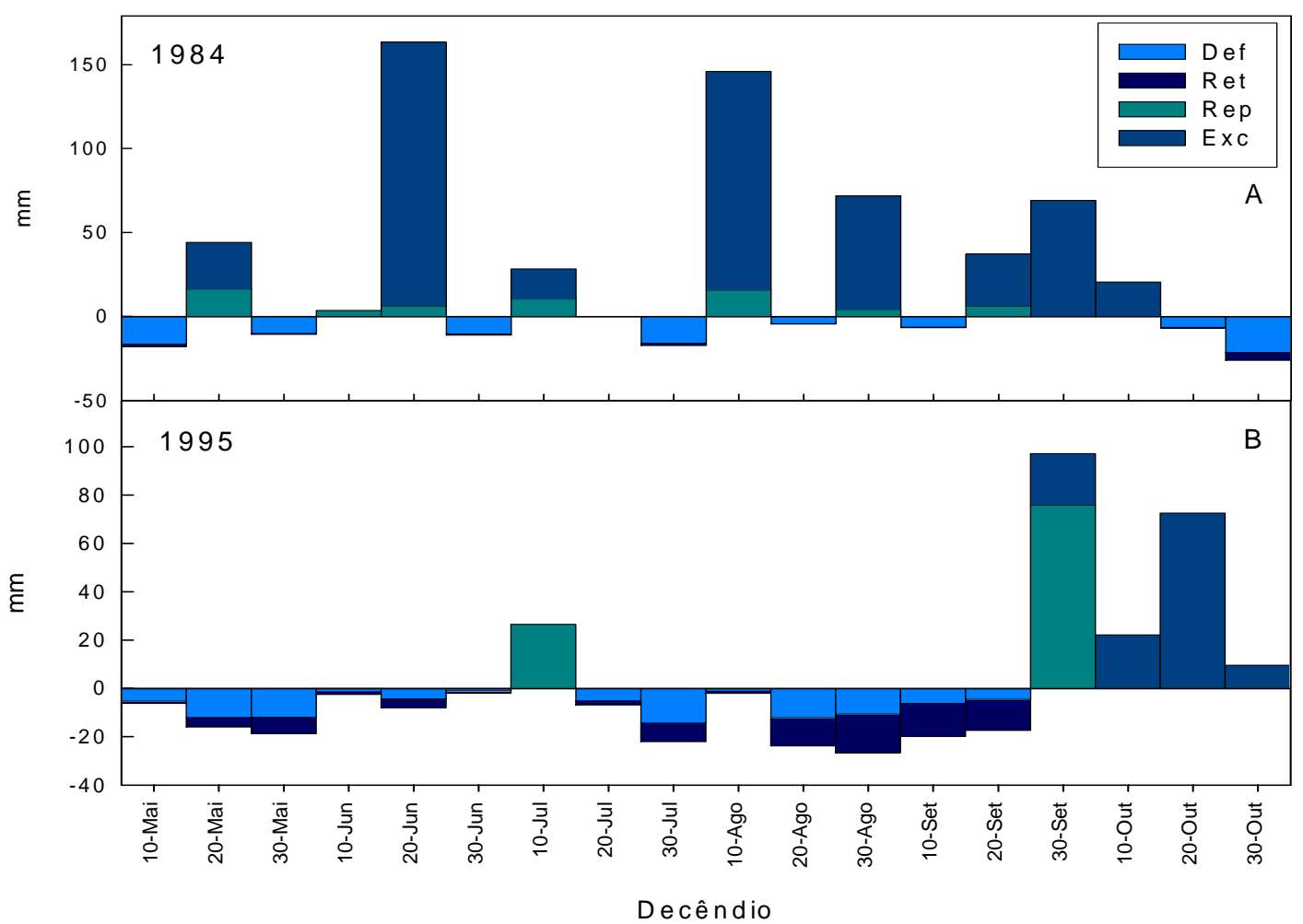

Figura 15- Balanço hídrico climatológico $(\mathrm{CAD}=100 \mathrm{~mm})$ para a região centro-oeste do Paraná, durante o cultivo em anos de acréscimo a produtividade

Quanto aos valores de IOS, houve 17 valores negativos e 10 positivos. Houve relação direta entre EN e valores negativos de IOS, com acréscimo a produtividade em 1986 e 1993 e 1998, e queda na maioria dos anos (1976, 1977, 1982, 1991, 1992, 1994 e 1997). A tendência para a região é de ano de EN estar relacionado a queda na produtividade (Tabela 6).

Em anos de LN observou-se 4 valores positivos e 2 negativos de IOS, que não podem ser relacionados com desvios na produtividade, visto que quando ocorreram valores negativos de IOS houve acréscimo a produtividade em 1995, queda em 1999, e não houve desvio em 1988.

Em anos NE houve 8 valores negativos e 3 positivos de IOS. Houve aumento na produtividade na maioria dos anos com valores negativos (Tabela 6). 
Tabela 6. Sinais de Valores mensais de Índice de Oscilação Sul (IOS) e desvio da produtividade de trigo na região centro-oeste do Paraná, de 1976 a 2002

\begin{tabular}{|c|c|c|c|}
\hline Evento & Valores de IOS & $\begin{array}{c}\text { Desvio de } \\
\text { produtividade }\end{array}$ & $\begin{array}{c}\text { Anos de } \\
\text { Ocorrência }\end{array}$ \\
\hline \multirow[t]{3}{*}{ El Niño } & 10 negativos & 3 positivos & 1986, 1993, 1998 \\
\hline & & & 1976, 1977, 1982, 1991, 1992, \\
\hline & & 7 negativos & 1994, 1997 \\
\hline \multirow[t]{5}{*}{ La Niña } & 2 negativos & 1 positivo & 1995 \\
\hline & & 1 negativo & 2001 \\
\hline & 4 positivos & 1 positivo & 1996 \\
\hline & & 2 negativos & 1999, 2000 \\
\hline & & 1 nulo & 1988 \\
\hline \multirow[t]{5}{*}{ Neutro } & 8 negativos & 6 positivos & 1980, 1983, 1984, 1985, \\
\hline & & & 1987, 2002 \\
\hline & & 2 negativos & 1978, 1981 \\
\hline & 3 positivos & 2 positivos & 1989, 1990 \\
\hline & & 1 negativo & 1979 \\
\hline
\end{tabular}

\section{5- Região Sul}

Nessa região o rendimento real médio era de $1,19 \mathrm{Mg} \mathrm{ha}^{-1}$ em 1976, e de 3,18 Mg ha-1 em 2002, com incremento médio ponto-a-ponto de 0,07 $\mathrm{Mg} \mathrm{ha}^{-1} \mathrm{ano}^{-1}$. A TT, determinada estatisticamente, indica incremento de 0,06 Mg ha-1 ano-1. A média do rendimento no período era de $1,87 \mathrm{Mg} \mathrm{ha}^{-1}$, enquanto que sem a TT (produtividade corrigida) passou a 1,34 Mg ha-1 (Figura 16 A, B). Nesse caso a tendência tecnológica não foi significativa, após eliminação da TT não houve variação significativa nos desvios de produtividade. (Figura $16 \mathrm{~B}$ ). 
Houve relação entre ocorrência de LN e acréscimo a produtividade. Os maiores desvios positivos foram observados em $1988\left(+0,81 \mathrm{Mg} \mathrm{ha}^{-1}\right), 2000(+0,65 \mathrm{M}$ $\left.\mathrm{ha}^{-1}\right)$ e $2002\left(+0,94 \mathrm{Mg} \mathrm{ha}^{-1}\right)$ (Figura 16 C). O balanço hídrico climatológico indica que o cultivo em 1988 pode ser considerado seco. Foi registrado chuva em junho, época de semeadura, e no $2^{\circ}$ decêndio de setembro, porém em quantidades insuficientes para provocar danos a cultura (Figura $17 \mathrm{~A}$ ).

Os maiores desvios negativos foram em anos NE, em 1979 (-0,53 Mg ha $\left.{ }^{-1}\right)$, 1985 (-1,07 $\left.\mathrm{Mg} \mathrm{ha}^{-1}\right), 1989$ (-0,43 $\left.\mathrm{Mg} \mathrm{ha}^{-1}\right)$.

Em 2000 (LN) e 2002 (NE) choveu durante todo o período de cultivo, mas em maior quantidade em 2002. Mesmo em condição inversa a 1988, houve acréscimo de +0,65 Mg ha ${ }^{-1}$ em 2000, e de +0,91 Mg ha ${ }^{-1}$ em 2002 (Figura 17 B e C). Em 1979 (NE) houve queda de $-0,53 \mathrm{Mg} \mathrm{ha}^{-1}$, e em 1985 (NE) foi -1,083 $\mathrm{Mg} \mathrm{ha}^{-1}$. Nesses dois anos as chuvas freqüentes a partir do $1^{0}$ decêndio de setembro coincidiram com florescimento, frutificação e final do ciclo (Figura 18 A).

Em 1982 (EN) a queda no rendimento foi $-0,36 \mathrm{Mg} \mathrm{ha}^{-1}$. O solo esteve com alta umidade durante todo o cultivo, principalmente na fase final (maturação), a partir do $1^{0}$ decêndio de outubro (Figura 18 B).

Em 1983 (NE) houve queda de -0,39 $\mathrm{Mg} \mathrm{ha}^{-1}$, e como em 1982, as chuvas foram freqüentes atrasando a semeadura, favorecendo as doenças no início do ciclo. A partir do $1^{0}$ decêndio de setembro as chuvas foram constantes, porém em menores proporções (Figura 18 C). Em 1985 (NE) houve a maior queda na produtividade, -1,08 $\mathrm{Mg} \mathrm{ha}^{-1}$ e observou-se alta umidade durante o período de cultivo (Figura $18 \mathrm{D}$ ).

O Balanço Hídrico climatológico da região sul mostra que o inverno é úmido na grande maioria dos anos, independente de EN/LN. Portanto, os desvios de produtividade não podem ser relacionados apenas às condições de umidade durante $o$ período de cultivo.

Quanto ao Índice de Oscilação sul, foram registrados 17 valores negativos e 10 positivos. Em anos de EN todos os valores foram negativos, sendo que em 6 anos ocorreram acréscimo na produtividade (1977, 1986, 1991, 1993, 1994 e 1998), e em 4 houve queda (1976, 1982, 1992 e 1997). 


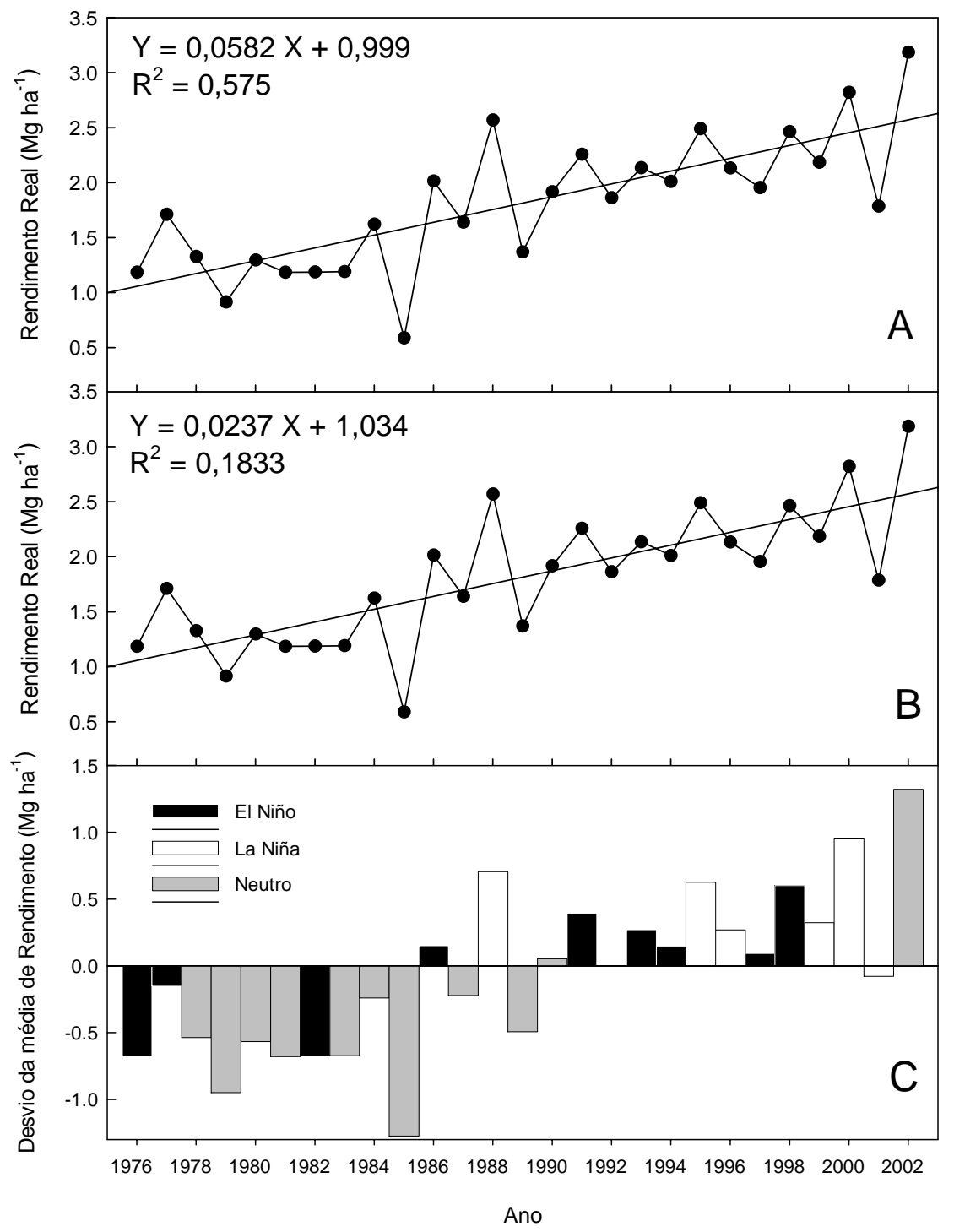

Figura 16- Séries históricas original (A), corrigida (B) e desvios da média de rendimentos corrigidos $(\mathrm{C})$ de grãos de trigo para a região sul do Paraná, de 1976 a 2002

Em anos de LN os valores de IOS foram 4 valores positivos com aumento na produtividade em todos os anos (1988, 1996, 1999 e 2000) e 2 valores negativos com aumento em 1995 e queda da produtividade em 2001. Em anos NE ocorreram 4 valores negativos e 7 valores positivos de IOS. Dos anos com IOS negativos, a produtividade 
aumentou em 1990 e 2002, e houve queda em 1979 e 1989. Em anos com IOS positivos não foi observado acréscimo e houve queda na produtividade em 1979, 1981 1983, 1984, 1985 e 1987.

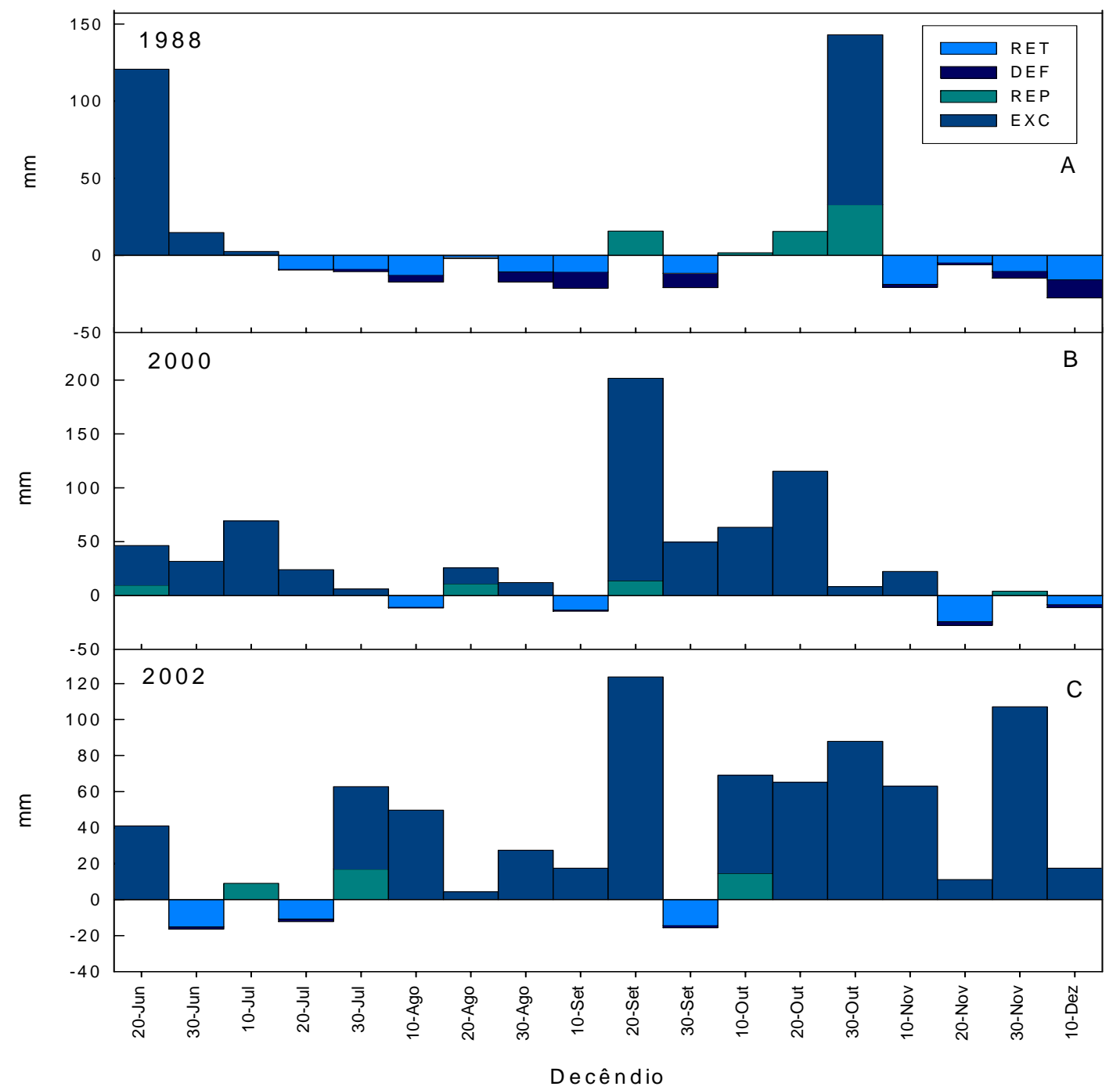

Figura 17- Balanço hídrico climatológico $(\mathrm{CAD}=100 \mathrm{~mm})$ para a região sul do Paraná, período de cultivo em anos de acréscimo a produtividade 


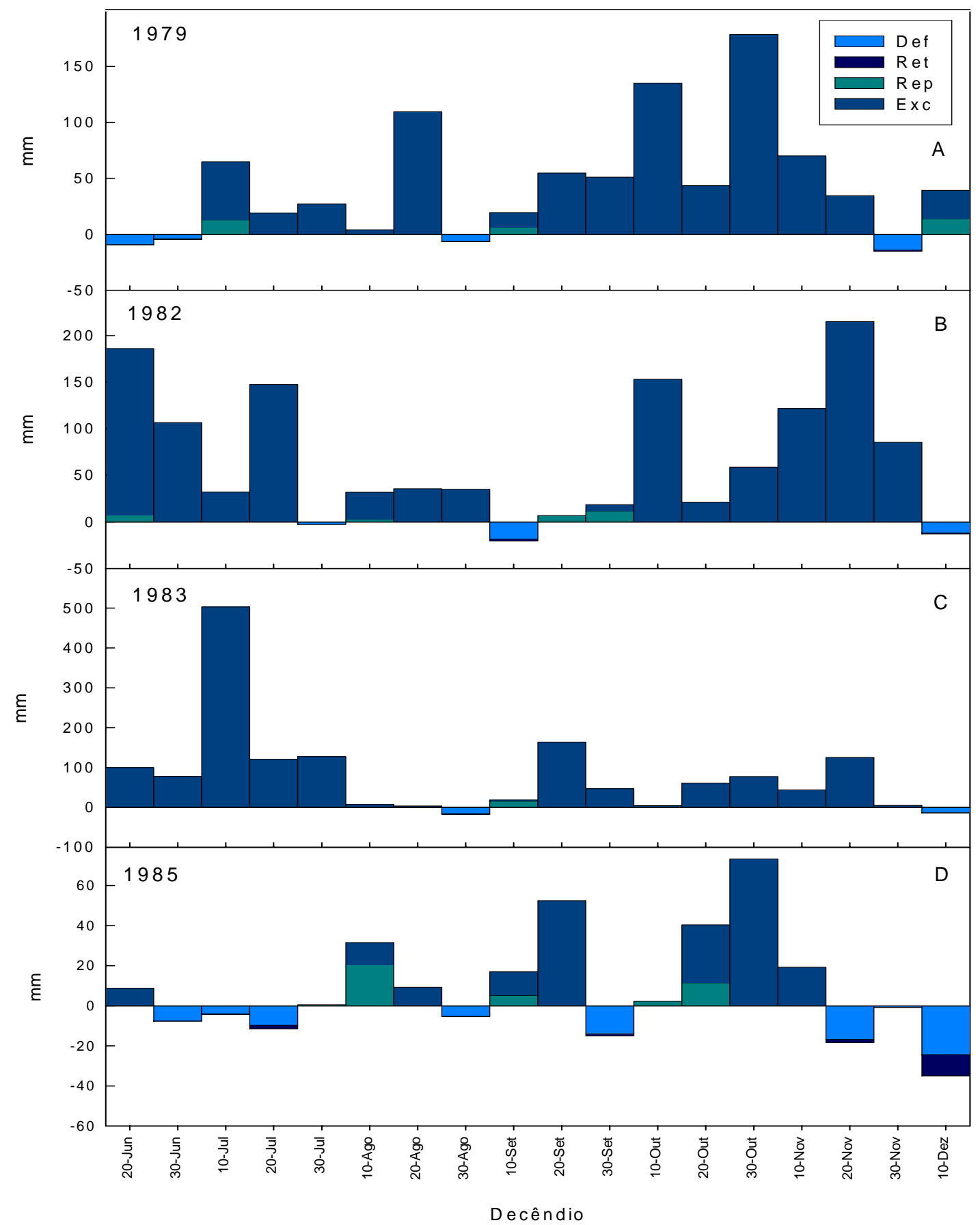

Figura 18- Balanço hídrico climatológico $(\mathrm{CAD}=100 \mathrm{~mm})$ para a região sul do Paraná, durante o cultivo em anos de queda de produtividade 
Tabela 7. Sinais de Valores mensais de Índice de Oscilação Sul (IOS) e desvio da produtividade de trigo na região sul do Paraná, de 1976 a 2002

\begin{tabular}{|c|c|c|c|}
\hline Evento & Valores de IOS & $\begin{array}{c}\text { Desvio de } \\
\text { produtividade }\end{array}$ & $\begin{array}{c}\text { Anos de } \\
\text { Ocorrência }\end{array}$ \\
\hline \multirow[t]{2}{*}{ El Niño } & 10 negativos & 6 positivos & $\begin{array}{l}\text { 1977, 1986, 1991, 1993, } \\
\text { 1994, } 1998\end{array}$ \\
\hline & & 4 negativos & 1976, 1982, 1992, 1997 \\
\hline \multirow[t]{3}{*}{ La Niña } & 4 positivos & 4 positivos & 1988, 1996, 1999, 2000 \\
\hline & 2 negativos & 1 positivo & 1995 \\
\hline & & 1 negativo & 2001 \\
\hline \multirow[t]{4}{*}{ Neutro } & 7 positivos & 6 negativos & $\begin{array}{l}\text { 1979, 1981, 1983, 1984, } \\
\text { 1985, } 1987\end{array}$ \\
\hline & & 1 nulo & 1980 \\
\hline & 4 negativos & 2 acréscimos & 1990, 2002 \\
\hline & & 2 negativos & 1979, 1989 \\
\hline
\end{tabular}

\section{6- Região Oeste}

A semeadura nessa região tem início a partir do $2^{\circ}$ decêndio de março, e ciclo variando de 120 a 140 dias, de acordo com as condições meteorológicas. O rendimento médio era de 0,95 $\mathrm{Mg} \mathrm{ha}^{-1}$ em 1976, e 2,4 $\mathrm{Mg} \mathrm{ha}^{-1}$ em 2002; um incremento médio ponto-a-ponto de $0,056 \mathrm{Mg} \mathrm{ha}^{-1}$ ano $^{-1}$. A TT determinada pelo ajuste estatístico indica incremento médio igual a 0,03 $\mathrm{Mg} \mathrm{ha}^{-1}$.(Figura $19 \mathrm{~A}$ ). A média do rendimento no período foi de 1,52 $\mathrm{Mg} \mathrm{ha}^{-1}$, enquanto que sem TT a média foi de 0,98 $\mathrm{Mg} \mathrm{ha}^{-1}$.(Figura $19 \mathrm{~B})$. 
Para essa região houve tendência a queda de produtividade em ano de EN. Os maiores acréscimos ao rendimento ocorreram em 1984, 1986, 1995 e 2002, e as maiores quedas em 1991, 1992 e 1999 (Figura 19 C).

Em 1984 (NE) ocorreu o maior desvio positivo, cerca de $+0,97 \mathrm{Mg} \mathrm{ha}^{-1}$. O balanço hídrico climatológico mostra ocorrência de chuva na época de semeadura e do $2^{0}$ decêndio de abril até final de maio. Próximo aos 60 dias após semeadura, no florescimento e início da frutificação, o solo se encontrava em condições favoráveis de umidade e não ocorreram chuvas, beneficiando esta fase da cultura. No final do ciclo o período seco foi favorável a maturação e colheita dos grãos (Figura 20 A).

Em 1986 (EN) houve um aumento cerca de +0,73 $\mathrm{Mg} \mathrm{ha}^{-1}$. Na época de semeadura, $2^{0}$ decêndio de maio, o solo se encontrava em condições satisfatórias de umidade e houve um período seco desde o $3^{\circ}$ decêndio de maio até o $2^{0}$ decêndio de abril. Choveu até $3^{\circ}$ decêndio de Maio, coincidindo o final das chuvas com início do florescimento. O período a seguir foi mais seco, sem chuva, porém com boas condições de umidade no solo, beneficiando o desenvolvimento da cultura. No final do ciclo houve chuva, porém insuficiente para causar danos a fase de maturação e colheita (Figura 20 B).

Em 1995 (LN) houve aumento de $+0,60 \mathrm{Mg} \mathrm{ha}^{-1}$. O período de cultivo foi caracterizado pela baixa ocorrência de chuvas, favorecendo a cultura, com baixa umidade, sem condições climáticas ao desenvolvimento de pragas e doenças (Figura 20 C).

Em 2002 (NE) o acréscimo ao rendimento foi em torno de $+0,63 \mathrm{Mg} \mathrm{ha}^{-1}$, e as condições de umidade no solo eram satisfatórias no período de semeadura, devido a chuvas anteriores. A ocorrência de chuva próximo aos 60 dias após a semeadura favoreceu ao florescimento e início da frutificação. A partir do $3^{\circ}$ decêndio de maio, as chuvas foram freqüentes coincidindo com a fase de enchimento de grãos. A seguir houve um período sem chuvas, favorecendo as fases de maturação e colheita (Figura 20 D).

Em 1991 (EN), 1992 (EN) e 1999 (LN) ocorreu queda de -0,38 $\mathrm{Mg} \mathrm{ha}^{-1}$ na produtividade. Nesses 3 anos o período chuvoso coincidiu com o florescimento podendo 
ter provocado queda de flores e infestação de moléstias afetando a produtividade (Figura 21 A, B e C).

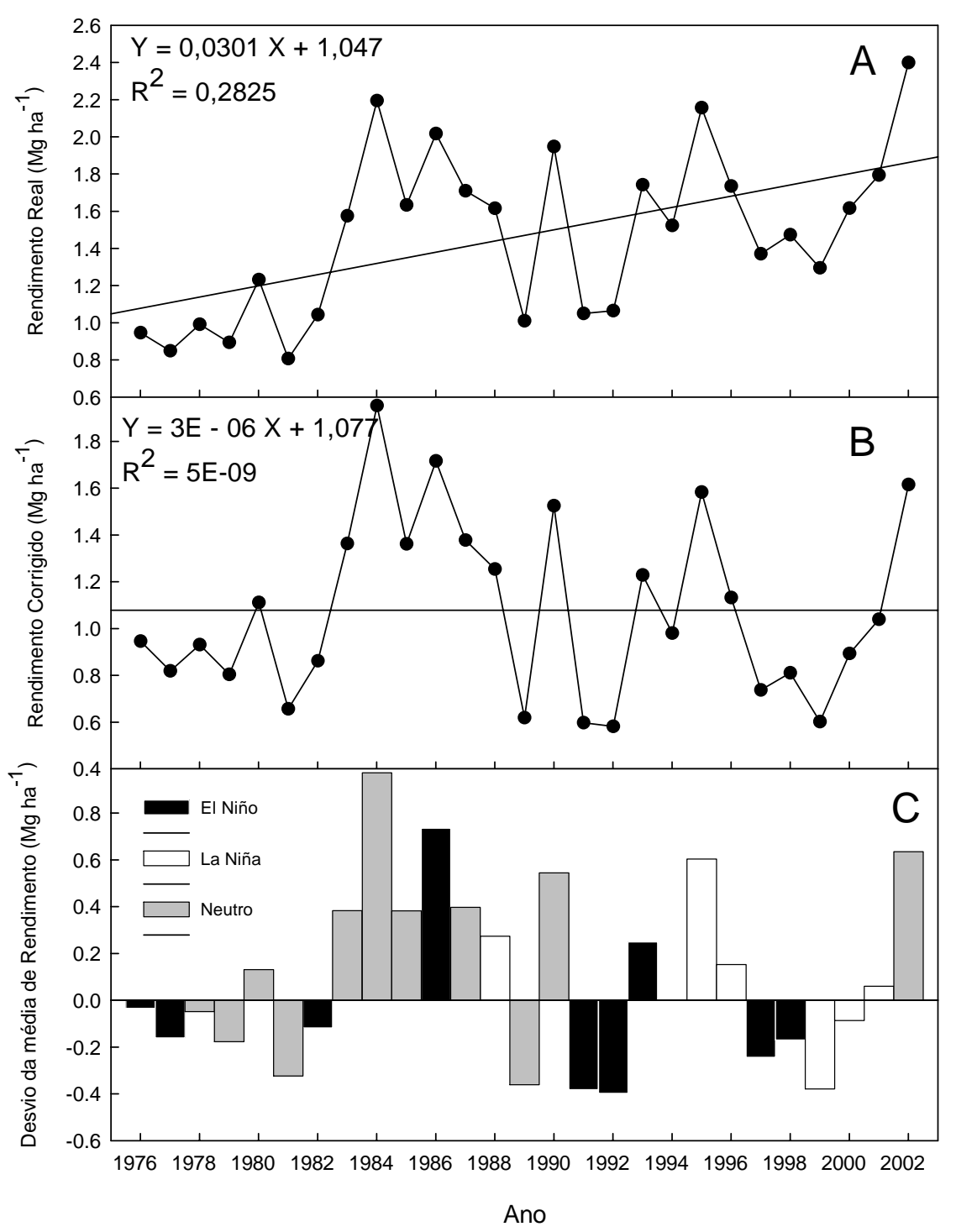

Figura 19- Séries históricas original (A), corrigida (B) e desvios da média de rendimentos corrigidos (C) de grãos de trigo para a região oeste do Paraná, de 1976 a 2002 
Nessa região ocorreram chuvas durante o período de cultivo, principalmente nas fase de florescimento, maturação e colheita dos grãos, o que favorece o desenvolvimento de pragas e doenças.

Foram registrados 17 valores mensais negativos e 10 valores positivos de IOS (Tabela 8). Em todos os anos de EN os valores de IOS foram negativos, com acréscimo na produtividade em 1986 e 1993, e queda na maioria dos anos de ocorrência (1976, 1977, 1982, 1991, 1992, 1997 e 1998). Em 1994 não foi observado desvio na produtividade.

Em anos de LN, a maioria dos valores de IOS foram positivos, com queda na produtividade em 1999 e 2000, e acréscimo em 1988 e 1996. Em 1995 houve acréscimo na produtividade com valores negativos de IOS.

Em anos NE foram registrados 6 valores positivos e 5 negativos de IOS. Em anos com valores positivos houve acréscimo a produtividade em 1983, 1984, 1985, e 1987, e queda em 1979 e 1981. Quando os valores de IOS foram negativos observou-se acréscimo a produtividade em 1980, 1990 e 2002) e queda em 1978 e 1989. 


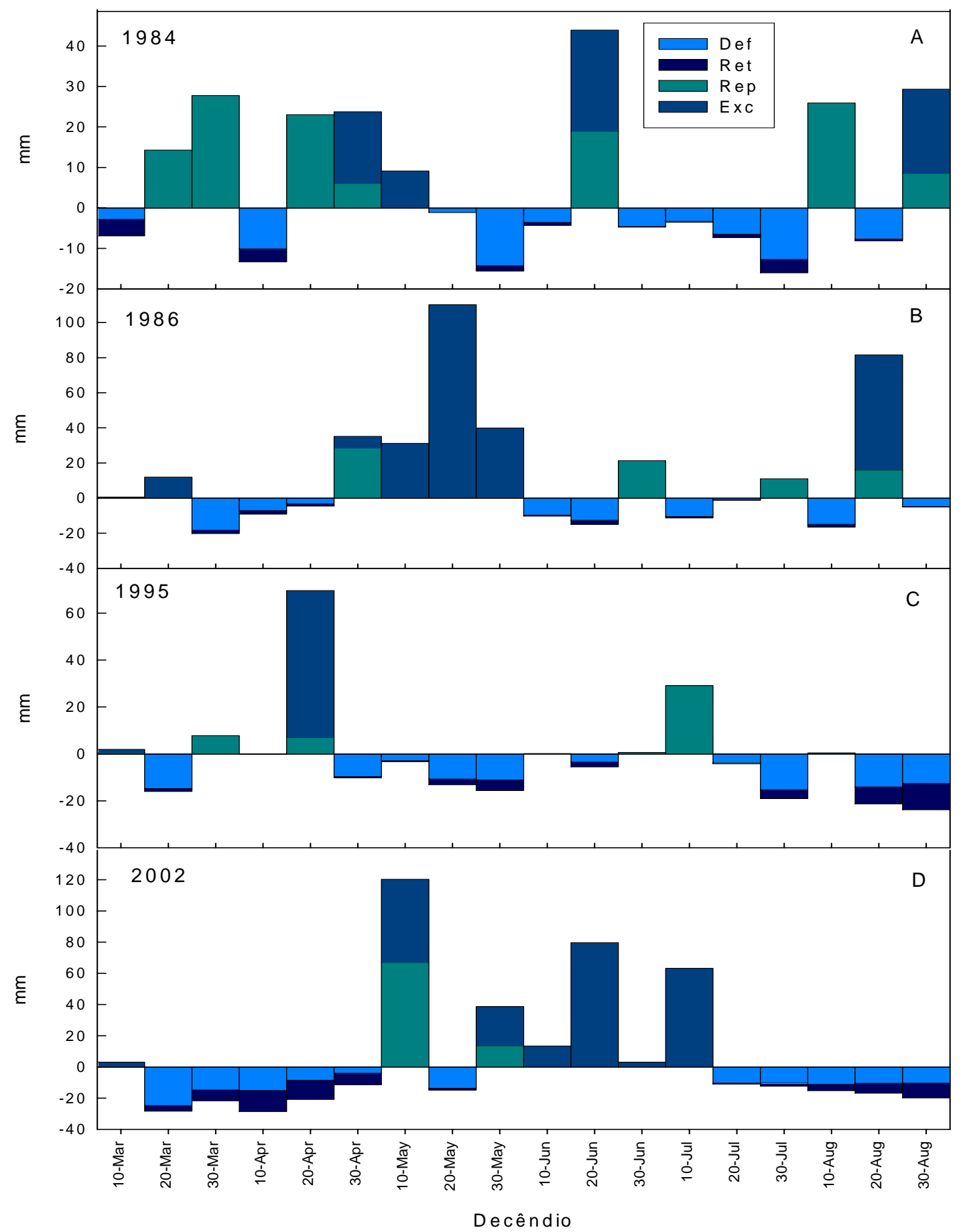

Figura 20- Balanço hídrico climatológico $(\mathrm{CAD}=100 \mathrm{~mm})$ para a região oeste do Paraná, durante o cultivo em anos de acréscimo a produtividade 


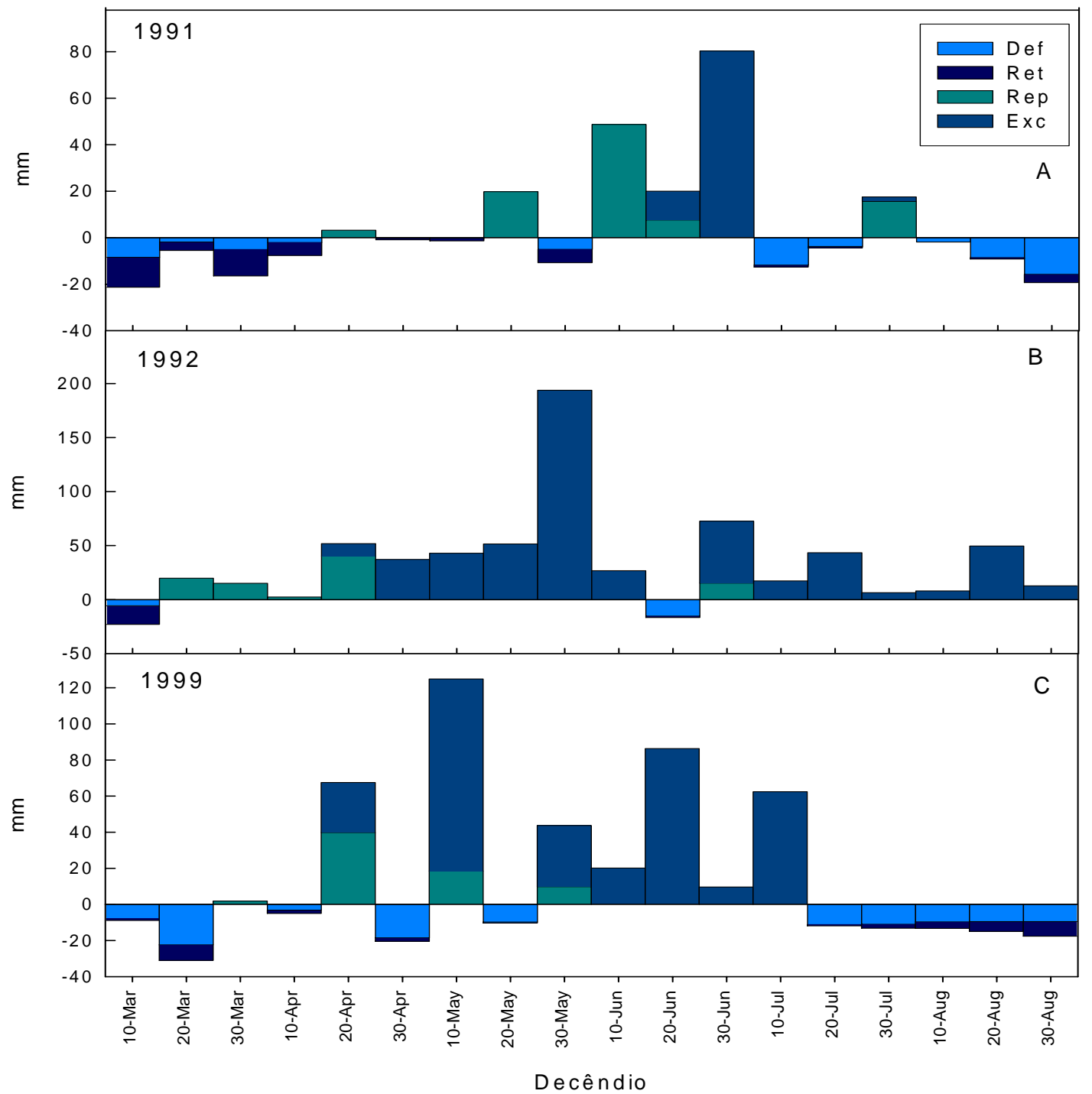

Figura 21- Balanço hídrico climatológico $(\mathrm{CAD}=100 \mathrm{~mm})$ para a região oeste do Paraná, durante o cultivo em anos de queda de produtividade 
Tabela 8 Sinais de Valores mensais de Índice de Oscilação Sul (IOS) e desvio da produtividade de trigo na região oeste do Paraná, de 1976 a 2002

\begin{tabular}{|c|c|c|c|}
\hline Evento & $\begin{array}{c}\text { Valores de } \\
\text { IOS }\end{array}$ & $\begin{array}{c}\text { Desvio de } \\
\text { produtividade }\end{array}$ & $\begin{array}{c}\text { Anos de } \\
\text { Ocorrência }\end{array}$ \\
\hline \multirow[t]{3}{*}{ El Niño } & 10 negativos & 2 positivos & 1986, 1993, \\
\hline & & 7 negativos & $\begin{array}{l}\text { 1976, 1977, 1982, 1991, } \\
\text { 1992, 1997, } 1998\end{array}$ \\
\hline & & 1 nulo & 1994 \\
\hline \multirow[t]{3}{*}{ La Niña } & 2 negativos & 2 positivos & 1995, 2001 \\
\hline & 4 positivos & 2 positivos & 1988, 1996 \\
\hline & & 2 negativos & 1999, 2000 \\
\hline \multirow[t]{4}{*}{ Neutro } & 6 positivos & 4 positivos & 1983, 1984, 1985, 1987 \\
\hline & & 2 negativos & 1979, 1981 \\
\hline & 5 negativos & 3 positivos & 1980, 1990,2002 \\
\hline & & 2 negativos & 1978, 1989 \\
\hline
\end{tabular}

Deve-se levar em consideração que os dados de chuva são pontuais e as análises estatísticas foram feitas com dados médios regionais, assim parte dos fatores não explicados podem ser atribuídos à variabilidade natural das chuvas. 


\section{CONCLUSÕES}

A análise de uma série histórica relativamente pequena de produtividade regional de trigo no Estado do Paraná permitiu inferir algumas conclusões a respeito dos efeitos dos fenômenos El Niño/La Niña sobre a triticultura regional. Ficou evidenciado que:

1 Nas regiões norte, noroeste e sudoeste não houve relação direta entre ocorrência de El Niño e desvios de produtividade regional. Nessas regiões a queda na produtividade foi relacionada à ocorrência de alta umidade nas fases de florescimento, maturação e colheita.

2 Nas regiões centro-oeste e oeste houve tendência à queda de produtividade em anos com El Niño.

3 Na região sul houve tendência ao acréscimo a produtividade em anos de La Niña. Nessa região, de inverno úmido e frio, os desvios de produtividade não podem ser atribuídos apenas às condições de umidade durante o período de cultivo.

4 Na região sudoeste houve tendência à queda de produtividade em anos de ocorrência de La Niña. 


\section{REFERÊNCIAS BIBLIOGRÁFICAS}

ALVES, J.M.B.; SOUZA, E.B. REPELLI, C.A.; FERREIRA, N.S. Um estudo da variabilidade pluviométrica no setor leste do nordeste brasileiro e a influência do fenômeno El Niño/Oscilação Sul. Revista Brasileira de Meteorologia, v.12, n.2, p. 25-40, 1997.

ASSIS, F.N.; MARTINS, S.R.; MENDES, M.E.G. Anomalias pluviométricas associadas a ocorrência de El Niño e La Niña no Rio Grande do Sul. In: CONGRESSO BRASILEIRO DE AGROMETEOROLOGIA, 10., Piracicaba, 1997. Anais. Piracicaba: ESALQ/USP - Sociedade Brasileira de Agrometeorologia, 1997. p. 283285.

ATLAS GEOGRÁFICO DO ESTADO DO PARANÁ. Secretaria do Estado da Agricultura e do Abastecimento/Instituto de Terras. Cartografias e Florestas, 73 p, Curitiba: SEAB, 1992.

ACEITUNO, P. On the functioning of southern oscillation in the South America sector. Part I: Surface Climate. Monthly Weather Review, v.116, p. 505-524, 1988.

BERLATO, M.A. The climate forecasting application in the decision-making process for the Southern Region of Brazil. IN: WORKSHOP report on ENSO and seazonal to inter-annual climate variability, socio-economic impacts, forecasting and applications to the decision-making process. Florianópolis, Santa Catarina, Brazil, 14-16 september, 1992 a. 
BERLATO, M.A. As condições de precipitação pluvial no Estado do Rio Grande do Sul e os impactos das estiagens na produção agrícola. In: BERGAMASCHI, H. (Coord.) Agrometeorologia Aplicada à Irrigação. Porto Alegre: Editora da Universidade / UFRGS. p. 11-23. 1992 b.

BRAGAGNOLO, N. Uso dos solos altamente suscetíveis à erosão. In: PEREIRA, V. P; FERREIRA, M.E.; CRUZ, M.C.P. (Ed). Solos altamente suscetíveis à erosão. Jaboticabal: UNESP/SBCS, 1992. p. 1-16.

CARAMORI, P.H.; OLIVEIRA, D.; FARIA, R.T. Freqüência de ocorrência de períodos com deficiência hídrica (verânicos) no Estado do Paraná. Londrina: IAPAR, 1991. 40p. (Boletim técnico, 36).

CARAMORI, P.H.; CAVIGLIONE, J.H.; WREGE, M.S.; GONÇALVES, S.L.; FARIA, R.T.; ANDROCIOLI FILHO, A.; SERA, T.; CHAVES, J.C.D.; KOGUISHI, M.S. Zoneamento de riscos climáticos para a cultura do café (Coffea arabica 1.) no Estado do Paraná. Revista Brasileira de Agrometeorologia, v.9, n.3, p. 486, 2001.

CPTEC/INPE. O El Niño: conseqüências do fenômeno sobre o território brasileiro e perspectivas para 1998. http://www.cptec.inpe.br. (18 maio 2004).

CUNHA, G.R. El Niño Oscilação do Sul e perspectivas climáticas aplicadas no manejo de culturas no sul do Brasil. Revista Brasileira de Agrometeorologia, v.7, n.2, p. 277-284, 1999.

CUNHA, G. R., DALMARGO, G.N., ESTEFANEL, V., PASINATO, A., MOREIRA, M.B. El Niño-Oscilação Sul e seus impactos sobre a cultura de cevada no Brasil. Revista Brasileira de Agrometeorologia, v.9, n.1, p.137-1345, 2001.

CUNHA, G.R. El niño - oscilação do sul: um fenômeno que influencia o clima e a agricultura de diferentes partes do mundo. Plantio Direto,n.29, p. 4-8, set./out. 1995. 
DARIO, G J., Instruções sumárias para a cultura do trigo no Estado de São Paulo. Piracicaba: ESALQ, 1988. p.9-14.

DOORENBOS, J.; KASSAN, A.H. Efectos del água sobre el rendimiento de los cultivos. Roma: FAO, 1979. 212p (Riego y drenage, 33).

EMPRESA BRASILEIRA DE PESQUISA AGROPECUÁRIA. Serviço Nacional de Levantamento de solos, Curitiba: EMBRAPA/IAPAR/SUDESUL, 1981. (Mapa, escala 1:600.000).

EVANS, L.T.; WARDLAW, I.F.; FISCHER, R.A. Wheat. In: EVANS, L.T., CROP PHYSIOLOGY - SOME CASE HISTORIES. Cambridge: Cambridge University Press, p.101-149, 1975. 374 p.

FONTANA, D. C.; BERLATO, M. A.Relação entre o El Niño Oscilação Sul (ENOS), precipitação e rendimento de milho no Estado do Rio Grande do Sul. Pesquisa Agropecuária Gaúcha, v.2, n.1, p.39 - 46, 1996.

FONTANA, D.C.; BERLATO, M.A. Influência do El Niño Oscilação Sul sobre a precipitação pluvial no Estado do Rio Grande do Sul. Revista Brasileira de Agrometeorologia, v.5, n.1, p.127-132, 1997.

GODOY, H,; BERNARDES, L.R.M. Clima e trigo no Paraná. In: MOTA, F.S., Agrometeorologia do trigo no Brasil. Campinas, SP: Sociedade Brasileira de Agrometeorologia, 1989. p. 36-56.

GRIMM, A.M.; GUETTER, A.K.; CARAMORI, P.H. El Niño no Paraná: o que se pode esperar em cada região. Uma análise científica. SIMEPAR - Curitiba, 1997, 9 p. (Informativo, 1).

GRODDZKI, L.; CARAMORI, P.H.; BOOTSMA, A.; OLIVEIRA, D.; GOMES, J. Risco de ocorrência de geada no Estado do Paraná. Revista Brasileira de Agrometeorologia, v.4, n.1, p. 939-999, 1996. 
GUERRA, J.R; CARAMORI, P.H. Influência dos fenômenos El Niño e La niña sobre a produtividade da cultura de milho no Estado do Paraná. In: CONGRESSO BRASILEIRO DE METEOROLOGIA, Anais, Foz do Iguaçu: Sociedade Brasileira de Agrometeorologia, p. 1223-1227, 2002.

IAPAR, INSTITUTO AGRONÔMICO DO PARANÁ, Londrina, Cartas Climáticas do Estado do Paraná, Londrina, 1994. 49p.

IBGE, INSTITUTO BRASILEIRO DE GEOGRAFIA E ESTATÍSTICA, www.ibge.com.br, (15 maio 2004).

INPE, INSTITUTO NACIONAL DE PESQUISAS ESPACIAIS www.cptec.inpe.br/products/laninha/lanitabp.html, (21 setembro 2004).

IPADES, INSTITUTO PARANAENSE DE DESENVOLVIMENTO ECONÔMICO E SOCIAL, Curitiba, PR. Atlas do Estado do Paraná. Curitiba, 1987. 73p.

KATZ, R.W. Sir Gilbert Walker and a conncection between El Niño and Statistcs. Statistical Science, v.17, n.1, p. 97-112, 2002.

KIRKHAM, M.B.; KANEMASU, E.T. Wheat. In: TEARE, I.D.; PEET, M.M. CropWater Relations. 1983. p.481-520.

KOUSKY, V.E; CAVALCANTI, I. F.A. Eventos Oscilação Sul - El Niño: características, evolução e anomalias de precipitação. Ciência e Cultura, vol. 36, n.11, 1984.

LAING, D.R.; FISCHER, R.A. Response of wheat under sub-humid irrigated conditions to atmospheric misting during grain filling. Agricultural and Forest Meteorology, v.15, n.4, p.285-293, 1975. 
LINHARES, A.G.; NEDEL, J.L. Clima e germinação do grão de trigo na espiga. In: MOTA, F.S., Agrometeorologia do trigo no Brasil. Campinas, SP: Sociedade Brasileira de Agrometeorologia, 1989. p. 95-101.

LOMAS, J. Meteorological requirements of the wheat crop. WMO SYMPOSIUM ON AGROMETEOROGY OF THE WHEAT CROP. Braunschweig, Federal Republic of Germany, 1976 ( WMO n. 396).

MANFRON, P.A.; LAZZAROTTO, C.; MEDEIROS, S.L.P. TRIGO - Aspectos agrometeorológicos. Ciência Rural, v.23, n.2, p.233-239, 1993.

MOLION, L.C.B. ENOS e o Clima no Brasil. Ciência Hoje, v.10, n.58, p. 23-29, 1989.

MOTA, F.S. Clima e zoneamento para a triticultura no Brasil. In: OSÓRIO, E.A. Trigo no Brasil. Campinas, SP. Fundação Cargill, 1982. p.29-61.

MOTA, F.S. Clima, tecnologia e produtividade do trigo no Brasil. In: MOTA, F.S., Agrometeorologia do trigo no Brasil. Campinas, SP: Sociedade Brasileira de Agrometeorologia, 1989. p.1-35

NICHOLLS, N. Use of the southern oscillation to predict Australian sorghum yield. Agricultural and Forest Meteorology, v.38, n.1/3, p/9-15, 1986.

RAO, V.B.; HADA, K. Characteristics of rainfall over Brazil, annual variation and correlation with the southern oscillation. Theoretical and Applied Climatology, v.2, p.81-91, 1990.

RAO, V.B; DE LIMA, M.C.; FRANCHITO, S.H.. Seasonal and interannual variations of rainfall over northeast Brazil. Journal of Climate, v.9, p. 1754-1763, 1993.

Reports to the Nation. El Niño and climate prediction. Washington: NOAA, UCAR. n.3, Spring 1994. 25p. 
RIMMINGTON, G.M.; NICHOLLS, N. Forecasting wheat yields in Australian with southern oscillation index. Australian Journal Agricultural Research, v.44, n.4, p. 625-632, 1993.

SILVA, A.R. da. Trigo no sul de Mato Grosso. Ministério da Agricultura, Instituto de Pesquisa Agropecuária do Oeste, 1971. 24 p.

SILVA , A. R. da, PINTO, M.M.; AZEVEDO, D da C. O clima no sul do Mato Grosso e a cultura do trigo. Departamento Nacional de Meteorologia, Série Pesquisa Meteorológica, n. 1, p.23,1973.

STUDZINSKI, C.D. Um estudo da precipitação na Região Sul do Brasil e sua relação com os oceanos Pacífico e Atlântico Tropical Sul. São José dos Campos. Instituto Nacional de Pesquisas Espaciais. 1995. 79p. Dissertação (Mestrado). 